\title{
Dulcor Misericordiae. Justicia y misericordia en el ejercicio de la autoridad canónica. II. El capítulo octavo de Amoris Laetitia
}

\author{
Dulcor Misericordiae. Justice and Mercy in the Exercise \\ of Canonical Authority. II. Chapter 8 of Amoris Laetitia
}

Javier OTADUY

Profesor Ordinario de Parte general y Derecho de la persona

Universidad de Navarra. Facultad de Derecho Canónico orcid 0000-0001-6446-852

jotaduy@unav.es

Resumen: El capítulo octavo de la Ex. Ap. Amoris Laetitia ha suscitado reacciones diversas, a veces encontradas. No puede decirse que el documento pontificio haya admitido a la comunión eucarística a los divorciados que se encuentran en nueva unión. La comprensión del capítulo octavo exige una cuidadosa interpretación in altum (integral y en profundidad). El objeto de la misericordia no es sólo el sufrimiento, sino ante todo la situación de pecado; y el sujeto de la misericordia no es sólo el que tiene miserias actuales sino también el sometido a la potencial fragilidad y miseria futura. La misericordia induce a aplicar las normas morales y jurídicas sin crueldad alguna, pero no a ignorarlas. El matrimonio no admite extensiones analógicas indiscriminadas porque no es un modelo meramente ideal. En el caso de las Ilamadas situaciones irregulares el acceso a la Eucaristía exige siempre la disposición de un cambio de vida.

Palabras clave: Justicia, Misericordia, Situación irregular, Comunión eucarística, Ex. Ap. Amoris Laetitia.
Abstract: Chapter 8 of Ap. Ex. Amoris Laetitia has given rise to different, sometimes contradictory readings. However, it cannot be said that the papal document extends Eucharistic communion to divorced people who have entered into new unions. Chapter 8 requires careful interpretation in altum (in full and in depth). The object of mercy is not only suffering, but first of all situation of sin; and the subject of mercy is not only the one currently experiencing misery, but anyone who may experience such fragility and misery in the future. Mercy implies that moral and legal norms be applied without any sense of cruelty, not that such norms be ignored. Marriage does not admit of indiscriminate analogical varieties, because it is not merely an ideal model. In the case of so-called irregular situations, reception of the Eucharist always requires the provision of a change in life.

Keywords: Justice, Mercy, Irregular Situation, Eucharistic Communion, Ap. Ex. Amoris Laetitia. 
$\mathrm{P}$ rosigo en este artículo la tarea de un artículo del número anterior de Ius Canonicum ${ }^{1}$. Ambos se acogen bajo el título Dulcor misericordiae. En el primer artículo di un repaso a la historia canónica de la aequitas. Ahora la misericordia se va a referir más estrictamente al modo de valorar las situaciones irregulares. Cuando se escribió el anterior artículo todavía no se había publicado la Ex. Ap. Amoris Laetitia, que sin duda alguna ha acaparado el protagonismo sobre la materia. Como es bien sabido la exhortación apostólica es un documento pontificio postsinodal, confeccionado después de dos sínodos sucesivos sobre la familia: el sínodo extraordinario sobre los desafíos pastorales de la familia en el contexto de la evangelización (5/19-X-2014); y el sínodo ordinario sobre la vocación y la misión de la familia en la Iglesia y en el mundo contemporáneo (4/25-X-2015). La Exhortación postsinodal Amoris Laetitia sobre el amor en la familia, del papa Francisco, lleva fecha de 19-III2016, y es un largo documento de 325 puntos y 267 páginas en la primera edición de la tipografía vaticana.

\section{La CONTINUIDAD O DisCONTINUIDAD DEL CAPÍTULO OCTAVO DE AMORIS LAETITIA}

Pedir a alguien en estos momentos que hable de la misericordia en relación con las situaciones irregulares es obviamente pedirle que haga un comentario al capítulo octavo de la Exhortación apostólica Amoris Laetitia. Su título es Acompañar, discernir e integrar la fragilidad. Convertido en un hecho social y comunicativo, ha velado en consecuencia buena parte de los contenidos de Amoris Laetitia sobre la familia.

Sobre dicho capítulo existe un grave conflicto de interpretaciones. El conflicto de las interpretaciones es el título de un conocidísimo libro de ensayos de Paul Ricoeur. Pero se ha empleado esta expresión precisamente para presentar el octavo capítulo de Amoris Laetitia ${ }^{2}$. Si nos remitimos al núcleo del núcleo, es decir, al punto más candente del capítulo octavo, la pregunta sobre la que versan las dudas interpretativas más agudas sería la siguiente: después de someter-

${ }^{1} \mathrm{~J}$. OTADUY, «Dulcor misericordiae». Fusticia y misericordia en el ejercicio de la autoridad canónica. I. Historia, Ius Canonicum 112 (2016) 585-619.

2 C. Caffarra, Intervista di Marco Ferrarese, La nuova Bussola Quotidiana, 25-V-2016 [goo.gl/6aCq5b]. Merece la pena, por presentar el contraste entre dos polos opuestos de interpretación, G. MARCOTULLIO, «Amoris letitia» tra Fellay e Melloni: letture ed errori, La Crocequotidiano.it, 16-IV-2016 [goo.gl/BRoUv1]. 
se a un proceso de discernimiento, ¿pueden los divorciados que se han vuelto a casar civilmente recibir los sacramentos sin abandonar la intimidad conyugal? Esto no es evidentemente un resumen del capítulo octavo de la Amoris Laetitia. Pero al menos nos permite presentar los puncta dolentia de la exhortación apostólica.

Las reacciones fundamentales ante la propuesta del capítulo octavo han sido cuatro. Hablo de las primeras impresiones, las que se han producido entre abril y noviembre de este año 2016. La primera reacción, abundante entre los medios de comunicación generalista, y bastante representativa también en ámbitos eclesiales, ha sido la de aprobar con entusiasmo que el Papa haya abierto la puerta a los divorciados para que reciban la Eucaristía. Afirman la existencia del cambio y lo aplauden ${ }^{3}$. La segunda reacción ha sido de consternación ante lo que se considera un cambio de la praxis pastoral que lleva consigo implícitamente un verdadero cambio en la doctrina ${ }^{4}$. La tercera reacción

${ }^{3}$ Cfr. por ejemplo, A. VALLINI, «La letizia dell'amore»: il cammino delle famiglie a Roma, 19-IX-2016 [goo.gl/9H2hf2]; J. ANTULA, La verdadera novedad de «Amoris Laetitia», Religión Digital, 21-IV2016 [goo.gl/lGeqKW]; W. KASPER, Entrevista, Aachener Zeitung/InfoCatólica, 22-IV-2016 [goo.gl/SWYxKI]; R. BLÁZQuEZ PÉREZ, Nell'Amoris Laetitia. Il magistero della gioia, L'Osservatore Romano, 15-IV-2016; R. ButTigLIONE, La gioia dell'amore e lo sconcerto dei teologi. A proposito di alcuni commenti sull'esortazione apostolica di papa Francesco «Amoris laetitia», L'Osservatore Romano, 20-VII-2016; A. Melloni, Francesco e la riforma dell'amore, La Repubblica.it, 9-IV-2016 [goo.gl/2tKio7]; A. FumaGalli, La «via caritatis». Sul capitolo ottavo di «Amoris Laetitia», La Rivista del Clero Italiano 2016/7-8 (citado por Settimo Cielo di Sandro Magister, 9-VIII-2016 [goo.gl/uVf1Z]); G. I. GARGANO, Una lettura di «Amoris Laetitia», camaldolesiromani.com [goo.gl/J8a6xf]; A. GriLlo, Alla scoperta di «Amoris Laetitia» (1-19), Munera, Rivista europea di cultura, cittadellaeditrice.com, 10-IV-2016/16-VII-2016 [goo.gl/ZT2Sg7]; R. GUERRA LóPEZ, Fedeltà creativa. Dalla riflessione di Karol Wojtyla all'esortazione «Amoris laetitia», L'Osservatore Romano, 23-VII-2016; Kathpress [Katholische Presseagentur], «Amoris laetitia». Theologen sehen Ortskirchen am Zug, Kath.net, 12-VI-2016 [goo.gl/eqLDul]; E. RaSMUSSEN, Francisco, de disimulado a condenado, Religión Digital, 28-IV-2016 [goo.gl/BCfMck]; Ch. SCHÖNBORN, Excerpt from Conversation with Cardinal Schönborn about Amoris Laetitia (Intervista di A. Spadaro), La Civiltà Cattolica [goo.gl/fU2RX7]; A. SPADARO, Struttura e significato dell'Esortazione apostolica postsinodale di papa Francesco, La Civiltà Cattolica, n. 3980, 23-IV-2016, 105-128; F. SEBASTiáN, ¿Amoris Laetitia ambigua?, Vida Nueva, n. 3002 (10/16-IX-2016), 9-IX-2016 [goo.gl/1bE6X7]; A. Spadaro - L. J. CAMELI, La sfida del discernimento in «Amoris Laetitia», La Civiltà Cattolica, n. 3985, 9-VII-2016, 3-16, cit. por The gift and challenge of discernment in «The foy of Love», America. The National Catholic Review, 1/8-VIII-2016 [goo.gl/A5hz1R]; J.-P. VESCO, Avec «Amoris laetitia», le pape François a fait cuvre de tradition, La Croix Urbi\&Orbi, 30-VI-2016 [goo.gl/fUognC]; S. B. VILLEGAS, «Amoris Laetitia». In the fubilee of Mercy, The Official Website of The Catholic Bishops' Conference of the Philippines, 9-IV-2016 [goo.gl/Q1gjJV].

${ }^{4}$ Cfr. por ejemplo, C. BARTHE, L'instinct de la foi, hommenouveau.fr, 8-IV-2016 [goo.gl/wBdM3p]; C. BARTHE, Entrevista de Roberto de Mattei, adelantelafe.com, 9-V-2016 [goo.gl/7zp5a9]; E. C. BRUGGER, Five serious problems with Chapter 8 of «Amoris Laetitia», Catholic World Report, 22IV-2016 [goo.gl/iUj0Qh]; J. MERECKI, Fedeltà troppo creativa diventa infedeltà, Settimo Cielo di 
ha sido la de los que afirman que, aunque no se haya dado lugar a un cambio sustancial en la doctrina, es indudable que se ha originado una situación positiva de ambigüedad y de incerteza, que producirá en el futuro numerosos problemas pastorales 5 . La cuarta y última postura dice que no ha ocurrido nada. Todo sigue como hasta ahora. La Exhortación apostólica Amoris Laetitia ni puede cambiar nada, ni desea cambiarlo, ni de hecho lo ha cambiado ${ }^{6}$.

Sandro Magister, 4-VIII-2016 [goo.gl/tzZ87J]; A. MorSELLI, Osservazioni su alcuni punti controversi dell'Esortazione apostolica «Amoris laetitia», Messainlatino.it, 29-V-2016 [goo.gl/ZO5uek]; A. SCHNEIDER, Il paradosso delle interpretazioni contraddittorie di "Amoris laetitia», Veri Catholici, 24-IV-2016 [goo.gl/DUh4Zk]; J. SEIFERT, Die Freude der Liebe: Freuden, Betrübnisse und Hoffnungen, Katholisches.info, 3-VIII-2016 [goo.gl/bg7vTP]; A. M. SILVAS, Some Concerns about «Amoris Laetitia» [goo.gl/Ity7jW]; R. SPAEMANN, Entrevista de Anian Cristoph Wimmer, CNA/InfoCatólica, 29-IV-2016 [goo.gl/VdQQna]; G. WoODALL, «Amoris laetitia», conciencia y discernimiento, CatolicosOn-line.org [goo.gl/tq7wTr]; C. PIERANTONI, La crisi ariana e la controversia attuale su «Amoris laetitia»: un parallelo, www.chiesa.espressonline.it, 28-XI-2016 [goo.gl/f5 gLDQ]. A esta lista se podrían añadir los nombres de bastantes autores netamente contrarios a Amoris Laetitia pero con un planteamiento que compromete la ecuanimidad de su juicio.

5 Cfr. por ejemplo, A. Bellon, Istruzioni per la lettura dell'esortazione postsinodale «Amoris latitia», Settimo Cielo di Sandro Magister, 5-V-2016 [goo.gl/bh3cKd]; C. CAFFARRA, «Amoris Laetitia». Il coraggio del cammino, Tracce.it, 12-IV-2016 [goo.gl/axQvWI]; C. CAFFARRA, Intervista di Marco Ferrarese, cit.; C. CAFFarRa, Interview by Maike Hickson, OnePeterFive, 11-VII-2016 [goo.gl/ ct4CBC]; A. GRaCián, Inconveniencias eclesiales, IV, V-VIII, InfoCatólica, 25-IV-2016/30-V-2016 [goo.gl/gLdGFf], [goo.gl/NgB4lB], [goo.gl/LxoR0C], [goo.gl/kDAHBI]; A. LIVI, Dottrina morale e prassi pastorale nella «Amoris laetitia», Unione Apostolica Fides et Ratio, 10-V-2016 [goo.gl/ GvleC6]; A. LIVI, Tante affermazioni che vanno chiarite, La nuova Bussola Quotidiana, 13-IV-2016 [goo.gl/4pNiJ2]; N. MARTÍNEZ, Algunas observaciones sobre la imputabilidad en «Amoris Laetitia», 9IV-2016 [goo.gl/lhrI77]; J. M. IRABURU, Amoris laetitia (1-9), InfoCatolica, 8-IV-2016/24-VI2016 [goo.gl/NmP0tG], [goo.gl/6fQIEP], [goo.gl/w1gT4f], [goo.gl/zGy6wy], [goo.gl/DePGcv], [goo.gl/oSkt71], [goo.gl/lncxyv], [goo.gl/TBv2EW], [goo.gl/pzHqv3]; J. A. SAYÉs, La misericordia de Dios en la «Amoris laetitia», CatólicosOn-line.org [goo.gl/0rJjg0]. Sin duda, la respuesta más significativa de este tipo ha sido la carta al papa Francisco de los cuatro cardenales, hecha pública el 14-XI-2016, en la que se presentan cinco dubia expresos sobre el contenido del capítulo octavo: Card. W. Branduüller - Card. R. L. Burke - Card. C. Caffarra - Card. J. Meisner, Fare chiarezza. Nodi irrisolti di «Amoris Laetitia». Un appello, chiesa.espresso.repubblica.it, 14-XI2016 [goo.gl/cSq1gF].

${ }^{6}$ Cfr. por ejemplo, Ch. J. Chaput, Pastoral Guidelines for Implementating «Amoris Laetitia», Archdiocese of Philadelphia, archphila.org, 1-VII-2016 [goo.gl/iClYXc]; E. ANTONELLI, Tra regole ed eccezioni, un difficile equilibrio, Settimo Cielo di Sandro Magister, 6-VII-2016 [goo.gl/nZ01eW]; A. Bagnasco, Presentazione alla Diocesi di Genova dell'Esortazione Apostolica «Amoris Laetitia», Avvenire, 15-IV-2016 [goo.gl/xV8Lch]; R. BuRKE, «Amoris Laetitia» and the Constant Teaching and Practice of the Church, National Catholic Register, 12-IV-2016 [goo.gl/aK0MXH]; C. J. ERRÁZURIZ MaCKenNa, Matrimonio y justicia objetiva en la comunión eclesial: un aspecto del discernimiento pastoral propiciado por «Amoris laetitia», Collationes, 25-V-2016 [goo.gl/fXfjgL]; J. GRANADOS, Intervista di Riccardo Cascioli, La nuova Bussola Quotidiana, 9-IV-2016 [goo.gl/oxQXM3]; D. MARAFioti, Una lettura dell'Essortazione «Amoris Laetitia», Ascolta 195 (2016) 2-3 [goo.gl/ pO9CsP]; L. Melina, Nota, Il Foglio, 11-IV-2016 [goo.gl/qlcPkV]; T. J. PAProcky, Catholics, marriage and Holy Communion, The State Journal-Register, 15-VII-2016 [goo.gl/0VULOz]; 
Muchos han leído Amoris Laetitia como si abriera el paso a la comunión de los divorciados vueltos a casar ${ }^{7}$. Es cierto que para ello hay que recurrir a un texto a pie de página que para muchos, incluso favorables a la introducción $^{8}$, es un modo sospechoso e insuficiente de tomar este tipo de decisiones. Es cierto que se emplea un modo condicional («podría»), no un modo absoluto $^{9}$. Es cierto también que ni siquiera el texto formula la cuestión con palabras expresas. El padre jesuita Domenico Marafioti decía hace poco: «Es necesario decir con toda sencillez que el Papa en Amoris Laetitia ha escrito más de 56.600 palabras, pero no ha escrito estas cinco [diez] simples palabras: "puede administrarse la comunión a los divorciados vueltos a casar". ¿Por qué no las ha escrito? Algún motivo hay. Si él no las ha escrito, considero que nadie las debe añadir, nadie debe hacer lo que él no ha hecho» ${ }^{10}$. Es cierto por último que se podría hacer una lectura textual en la que todas las expresiones remitieran de un modo u otro a la doctrina anterior, llevadas in meliorem par-

J. PÉREZ SOBA, Interpretar a partir del corazón del Evangelio, InfoCatólica, 23-II-2016 [goo.gl/ yY2jWf]; J. PÉREZ SOBA, «Amoris letitia» no es un cambio de doctrina, sino una invitación para un camino nuevo, InfoCatólica, 10-IV-2016 [goo.gl/f71LsQ]; J. PÉREZ SobA, Entrevista de Sergio Mora, Zenit, 11-IV-2016 [goo.gl/APX0bD]; A. RoDRíGUEZ LUÑO, «Amoris Laetitia»: Pautas doctrinales para un discernimiento pastoral, eticapolítica.net [goo.gl/FXWBQk]; J. E. DE OLIVEIRA, Chaves de leitura para «Amoris letitia», Collationes [goo.gl/mt73Uq]; A. VINGT-Trois, Pour un «art du discernement», fr.Zenit.org, 8-IV-2016 [goo.gl/N74ixi].

7 Una visión moderada de esta opinión puede verse en la posición de los OBISPOS DE LA REGIÓN DE BuEnos AIREs, Intercambio de cartas con el papa Francisco sobre los «Criterios básicos para la aplicación del capitulo 8 de Amoris Laetitia», Il Sismografo, 11-IX-2016 [goo.gl/i0eaNQ], con la que se manifiesta de acuerdo el papa Francisco: «En otras circunstancias más complejas, y cuando no se pudo obtener una declaración de nulidad, la opción mencionada puede no ser de hecho factible. No obstante, igualmente es posible un camino de discernimiento. Si se llega a reconocer que, en un caso concreto, hay limitaciones que atenúan la responsabilidad y la culpabilidad (cfr. 301-302), particularmente cuando una persona considere que caería en una ulterior falta dañando a los hijos de la nueva unión, Amoris laetitia abre la posibilidad del acceso a los sacramentos de la Reconciliación y la Eucaristía (cfr. notas 336 y 351). Éstos a su vez disponen a la persona a seguir madurando y creciendo con la fuerza de la gracia» (OBISPOS DE LA REGIÓN DE BUENOS AIRES, Intercambio de cartas con el papa Francisco sobre los «Criterios básicos para la aplicación del capítulo 8 de Amoris Laetitia», Il Sismografo, 11-IX-2016 [goo.gl/i0eaNQ]).

8 Cfr. por ejemplo, A. Fumagalli, La «via caritatis». Sul capitolo ottavo di «Amoris Laetitia», La Rivista del Clero Italiano 2016/7-8 (citado por Settimo Cielo di Sandro Magister, 9-VIII-2016 [goo.gl/uVf1Z]).

9 «Il testo dell'Esortazione Apostolica non va oltre, ma nella nota 351 si legge: "In certi casi, potrebbe essere anche l'aiuto dei sacramenti". Il Papa usa il condicionale, dunque non dice che bisogna ammettere ai sacramenti, sebbene non lo escluda in alcuni casi e ad alcune condizioni» (A. VALLINI, «La letizia dell'amore»: il cammino delle famiglie a Roma, 19-IX-2016 [goo.gl/9H2hf2]).

10 D. Marafioti, Una lettura dell'Essortazione «Amoris Laetitia», Ascolta 195 (2016) 2 [goo.gl/ pO9CsP]. 
tem. Para hacerlo, Angelo Bellon escribió por ejemplo unas cuidadas instrucciones ${ }^{11}$. Todos aquellos que dicen que Amoris Laetitia no ha cambiado nada apoyan esta posición.

Pero para muchos «parece ridículo decir que no ha cambiado nada $\gg^{12}$. No es extraño que muchos hayan leído Amoris Laetitia como si abriera el paso a la comunión de los divorciados en nueva unión, porque el texto, respetando las reglas de la gramática, consiente esa lectura ${ }^{13}$. Ahora bien, ¿se puede afirmar eso con garantías? Es decir, ¿existe un fundamento moral y jurídico para afirmarlo?, ¿es verdaderamente eso lo que quiere el documento?

Para asentar esta hipotética nueva praxis en algún fundamento jurídico se pueden seguir (se han seguido de hecho) tres caminos.

El primero es por derogación de la norma antigua. Veamos cómo funcionaría este argumento. Si se establece en un documento pontificio las condiciones necesarias para que puedan recibirse los sacramentos sin necesidad de abandonar una situación objetiva de pecado se está estableciendo una norma permisiva de gran alcance. No se está dispensando de una norma en un caso particular, se está estableciendo otra para hipotéticos casos futuros. La contradicción directa de la norma nueva con la antigua es una manera natural de derogar la norma antigua. No hace falta que haya una derogación expresa de las normas anteriores. Todas las indicaciones contrarias a Amoris Laetitia en los documentos pontificios anteriores podrían considerarse derogadas.

${ }^{11}$ A. BeLlon, Istruzioni per la lettura dell'esortazione postsinodale «Amoris letitia», Settimo Cielo di Sandro Magister, 5-V-2016 [goo.gl/bh3cKd].

12 J. Antula, La verdadera novedad de «Amoris Laetitia», Religión Digital, 21-IV-2016 [goo.gl/ lGeqKW].

13 A veces la lectura ha sido radical e inmediata, incluso entre el espiscopado. Tal vez el ejemplo más clamoroso sucedió en Filipinas: «Después de un estudio colegial, vuestros obispos ofrecerán directrices más concretas sobre la aplicación de la exhortación apostólica. Pero la misericordia no puede esperar. La misericordia no debe esperar. Ya desde ahora, obispos y sacerdotes deben abrir sus brazos a los que se han mantenido fuera de la Iglesia por un sentimiento de culpa y de vergüenza. Los laicos deben hacer lo mismo. Vayamos, como nos pide con urgencia el Papa, al encuento de nuestros hermanos y hermanas que, debido a sus relaciones rotas, a sus familias rotas y a sus vidas rotas, se quedan tímidamente a las puertas de nuestras iglesias -y de nuestras vidas- sin saber si son bienvenidos o no. Asegurémosles que en la mesa de los pecadores en la que el Santísimo Señor se ofrece a sí mismo como alimento para los miserables, siempre hay sitio. O res mirabilis manducat Dominum pauper, servus et humilis... ¡Oh qué admirable! Se alimentan del Señor los pobres, los siervos y los humildes. Es una actitud de misericordia, una apertura de corazón y de espíritu que no necesita ninguna ley, que no debe esperar ninguna directriz, que no debe aguardar estímulos nuevos. Puede y debe suceder inmediatamente» (S. B. VILLEGAS, «Amoris Laetitia». In the Jubilee of Mercy, The Official Website of The Catholic Bishops' Conference of the Philippines, 9-IV-2016 [goo.gl/Q1gjJV] [traducción propia]). 
Pero es muy difícil aceptar que un documento que se propone explícitamente no introducir una nueva normativa canónica pueda tener carácter derogatorio de la anterior normativa. Sería discutible si puede hacerlo, pero parece indiscutible que no quiere hacerlo. Estoy hablando de normativa en sentido amplio. Amoris Laetitia no quiere derogar las disposiciones del n. 84 de Familiaris Consortio, del n. 34 de Reconciliatio et Paenitentia, del n. 1650 del Catecismo de la Iglesia Católica, del c. 915 del Código de derecho canónico, y del n. 29 de Sacramentum Caritatis.

El segundo modo de justificar la nueva praxis pone los ojos en la relación entre norma y concesión singular. Cuando se concede a un divorciado en situación irregular el acceso a la comunión eucarística, esa concesión sería compatible con las normas anteriores. ¿Por qué? Porque cada categoría tendría su ámbito de validez. Las normas serían el ideal genérico, la decisión pastoral sería la excepción misericordiosa. Lo único que pretendería Amoris Laetitia es establecer una praxis de discernimiento para las situaciones singulares. No sería más que una profundización o un despliegue de la doctrina anterior. Un ejercicio del derecho más elevado en sus motivaciones y más pegado a la tierra en su ejercicio. Como consecuencia, la doctrina anterior no necesitaría ser desalojada ni derogada. Simplemente se ha producido, en palabras del cardenal Walter Kasper, un cambio de paradigma. «Un cambio de paradigma no cambia la enseñanza anterior; lo que hace es situar esa enseñanza en un contexto más amplio. De modo que Amoris Laetitia no cambia ni una iota de la enseñanza de la Iglesia, y sin embargo lo cambia todo» ${ }^{14}$.

Pero esta opinión parece también muy difícil de sostener. No sólo se deben respetar las reglas de la gramática sino también las reglas de la tradición, del derecho y del sentido común. Si Amoris Laetitia no cambia nada pero lo cambia todo, eso no es un cambio de paradigma sino una trampa. Es completamente cierto que la unidad entre doctrina y praxis «no impide que subsistan diferentes maneras de interpretar algunos aspectos de la doctrina o algunas consecuencias que se derivan de ella» (AL, 3). Pero para que dos verdades o dos valores tengan una validez simultánea es necesario que sean compatibles entre sí. Una perspectiva nueva que contradice la anterior no es un desarrollo, sino una negación de ella ${ }^{15}$. Las normas anteriores fundaban sus argumentos

\footnotetext{
${ }^{14}$ W. KASPER, «Amoris laetitia»: Bruch oder Aufbruch?, Stimmen der Zeit (2016/11) 725-726.

15 «Il cap. VIII, oggettivamente, non è chiaro. Altrimenti come si spiegherebbe il "conflitto di interpretazioni" accesosi anche tra vescovi? Quando ciò accade, occorre verificare se vi siano altri testi
} 
precisamente sobre la imposibilidad de excepción en esta materia. La indisolubilidad del matrimonio, la ilicitud de las relaciones sexuales en una segunda unión ${ }^{16} \mathrm{y}$ la necesidad de un verdadero arrepentimiento para poder recibir el perdón ${ }^{17}$ constituyen verdades que no admiten excepción. Por tanto si aceptáramos excepciones no tendríamos una visión desarrollada, sino que tendríamos dos visiones contradictorias.

El tercer modo, por fin, dice que no existe en realidad ninguna praxis nueva. Sencillamente, operan los principios elementales del derecho y de la teología moral. El discernimiento no haría otra cosa que descubrir que en esos casos el sujeto no tenía condiciones para que la norma le obligara. Los eximentes o los atenuantes viciarían su voluntad o su conocimiento. Así pues, no se trataría siquiera del levantamiento de la obligación para un caso. El sujeto no estaba obligado y el discernimiento lo pone en evidencia. Es un descubrimiento de la exención, no una dispensa de la obligación.

del Magistero più chiari, tenendo a mente un principio: in materia di dottrina della fede e di morale il Magistero non può contraddirsi. Non si devono confondere contraddizione e sviluppo. Se dico $\mathrm{S}$ è $\mathrm{P}$ e poi dico $\mathrm{S}$ non è $\mathrm{P}$, non è che abbia approfondito la prima. L'ho contraddetta» (C. CAFFARRA, Intervista di Marco Ferrarese, La nuova Bussola Quotidiana, 25-V-2016 [goo.gl/6aCq5b]).

$16 \ll \mathrm{El}$ proceso de discernimiento tiene que ser coherente también con la doctrina católica sobre la indisolubilidad del matrimonio, cuyo valor y actualidad el papa Francisco subraya fuertemente. La idea de que las relaciones sexuales en el contexto de una segunda unión civil son lícitas, comporta que esa segunda unión se considera un verdadero matrimonio, y entonces se entra en contradicción objetiva con la doctrina sobre la indisolubilidad, según la cual el matrimonio rato y consumado no puede ser disuelto, ni siquiera por la potestad vicaria del Romano Pontífice [san Juan Pablo II, en su discurso a la Rota Romana, del 21-I-2000, n. 8, declaró que esa doctrina ha de tenerse definitivamente]; si, en cambio, se reconoce que la segunda unión no es un verdadero matrimonio, porque verdadero matrimonio es y sigue siendo sólo el primero, entonces se acepta un estado y una condición de vida que "contradicen objetivamente la unión de amor entre Cristo y la Iglesia, significada y actualizada en la Eucaristía" [SAN JuAN PABLO II, Exh. Ap. Familiaris consortio, 22-XI-1981, n. 84]. Si, además, la vida more uxorio en la segunda unión se considerase moralmente aceptable, se negaría el principio fundamental de la moral cristiana según el cual las relaciones sexuales sólo son lícitas dentro del matrimonio legítimo» (A. RoDRíGUEZ LUÑO, «Amoris Laetitia»: Pautas doctrinales para un discernimiento pastoral, 2 [goo.gl/ FXWBQk]).

$17 \ll$ Por lo que concierne a los sacramentos de la Penitencia y de la Eucaristía, la Iglesia ha enseñado siempre y en todo lugar que "quien tiene conciencia de estar en pecado grave debe recibir el sacramento de la Reconciliación antes de acercarse a comulgar". La estructura fundamental del sacramento de la Reconciliación "comprende dos elementos igualmente esenciales: por una parte, los actos del hombre que se convierte bajo la acción del Espíritu Santo, a saber, la contrición, la confesión de los pecados y la satisfacción; y por otra parte, la acción de Dios por ministerio de la Iglesia" [CEC 1488]. Si faltase del todo la contrición perfecta o imperfecta (atrición), que incluye el propósito de cambiar de vida y evitar el pecado, los pecados no podrían ser perdonados, y si no obstante la absolución fuese impartida, la absolución sería inválida [cfr. CEC 1451-1453; Concilio de Trento, Sess. XIV, Doctrina de sacramento paenitentiae, cap. 4 (Dz-Hu. 1676-1678)]» (A. RodrígueZ LuÑo, «Amoris Laetitia»: Pautas doctrinales para un discernimiento pastoral, cit.). 
Tendremos ocasión de hablar sobre la imputabilidad en Amoris Laetitia. Pero digamos desde ahora que tampoco este planteamiento es convincente. Baste pensar lo siguiente: si estuviéramos ante un supuesto meramente declarativo, en el que se recuerda algo que todos sabemos, algo que está contenido en cualquier praxis confessariorum, ¿qué razón existiría para que se haya producido este terrible conflicto de interpretaciones?

Pienso sinceramente que ninguno de los procedimientos jurídicos que he presentado permiten afirmar que se ha introducido una nueva praxis pastoral en esta materia. Dicho de otra manera, a mi parecer, quien quisiera afirmar la nueva praxis pastoral se fundaría en un error. Me parece que el documento, mirado objetivamente, no quiere eso.

Ha habido voces muy respetables que han dicho que Amoris Laetitia no encierra ambigüedad alguna, al contrario, que es un ejemplo de claridad ${ }^{18}$, o que «al igual que leemos el concilio de Nicea a la luz del concilio de Constantinopla y el concilio Vaticano I a la luz del concilio Vaticano II, ahora tenemos que leer las afirmaciones anteriores del magisterio sobre la familia a la luz de las aportaciones que hace Amoris Laetitia ${ }^{19}$. Esta última estimación del cardenal Christoph Schönborn es muy cierta. Amoris Laetitia es un acto de magisterio del romano Pontífice, es una exhortación apostólica ${ }^{20}$. Su función natural es inscribirse en la línea de la doctrina magisterial, iluminarla, vivificarla, como hace en todas las cuestiones de las que trata. Si en algún asunto se suscita la duda habrá que intentar leerla de modo que sus palabras sean compatibles con la doctrina anterior, no en contraste con ella. $\mathrm{Al}$ menos hasta que las normas anteriores sean explícitamente derogadas.

¿Tienen algún sentido entonces las palabras de Amoris Laetitia en lo referente a la comunión a los divorciados vueltos a casar? A mi parecer no se pueden admitir novedades en el caso de esposos que no deseen remover su situación objetiva de pecado. $\mathrm{Y}$ desde luego sí en todos los demás casos, en los que están dispuestos a hacerlo, aunque sea con temor por el incumplimiento

${ }^{18}$ Cfr. F. Sebastián, ¿Amoris Laetitia ambigua?, cit. [goo.gl/1bE6X7].

19 Ch. SCHÖnBoRn, Excerpt from Conversation with Cardinal Schönborn about Amoris Laetitia (Intervista di A. Spadaro), cit. [goo.gl/fU2RX7] [traducción propia].

20 Sobre la condición de acto de magisterio, cfr. J. BOGARín DíAZ, Repercusiones canónicas de «Amoris Laetitia», Revista General de Derecho Canónico y Derecho Eclesiástico del Estado 41 (2016) (RI § 417440); R. GuERRA LóPEZ, Fedeltà creativa. Dalla riflessione di Karol Wojtyla all'esortazione «Amoris laetitia», L'Osservatore Romano, 22-VII-2016 [goo.gl/ORY9XS]. 
de su propósito ${ }^{21}$. Amoris Laetitia hace una referencia a este punto, remitiendo a un discurso de Juan Pablo II a la Penitenciaría Apostólica: «Una cosa es la existencia del propósito sincero, y otra el juicio de la inteligencia sobre el futuro. Es posible en efecto que, aun siendo leal el propósito de no volver a pecar, la experiencia del pasado y la conciencia de la debilidad actual susciten el temor de nuevas caídas; pero eso no prejuzga la autenticidad del propósito, cuando a ese temor va unida la voluntad, apoyada por la oración, de hacer lo que es posible para evitar la culpa» ${ }^{22}$. Tal vez se podría añadir la situación del cónyuge que tiene propósito de vivir la continencia, pero al que la intimidad conyugal le viene impuesta contra su voluntad por el otro cónyuge.

El cardenal Ennio Antonelli ha presentado con sencillez un hipotético caso de discernimiento: «el sacerdote confesor puede encontrarse con un divorciado vuelto a casar que cree sincera e intensamente en Jesucristo, que lleva un estilo de vida comprometido, generoso, capaz de sacrificio, que reconoce que su vida de pareja no se corresponde con la norma evangélica, pero considera que no comete pecado por las dificultades que le impiden observar la continencia sexual. Por su parte el confesor lo acoge con cordialidad y respeto; le escucha con bondadosa atención, con intención de hacerse cargo de los múltiples aspectos de su personalidad. Le ayuda además a hacer que sus

${ }^{21}$ En este sentido me parece sumamente ilustrativo lo que escribía Pablo VI en Humanae vitae, para una opción moral a veces tan dura o más dura que la que se pide a los divorciados en nueva unión: «Afronten los esposos los necesarios esfuerzos, mantenidos por la fe y la esperanza que "no defrauda, porque el amor de Dios ha sido derramado en nuestros corazones con el Espíritu Santo, que se nos ha dado"; imploren con perseverante oración la ayuda divina; alcancen, sobre todo en la Eucaristía, la fuente de la gracia y de la caridad. Si el pecado aún hiciera presa en ellos, no se desanimen, sino que acudan con humilde perseverancia a la misericordia de Dios, que es derramada con abundancia en el sacramento de la penitencia» (PABLO VI, Enc. Humance vite [25-VII-1968], 25); «No menoscabar en nada la saludable doctrina de Cristo es una forma de caridad eminente hacia las almas. Pero esto debe ir acompañado siempre de la paciencia y de la bondad de que el mismo Señor dio ejemplo en su trato con los hombres. Venido no para juzgar sino para salvar (cfr. Jn 3,17). Él fue ciertamente intransigente con el mal, pero misericordioso con las personas. Que en medio de sus dificultades encuentren siempre los cónyuges en las palabras y en el corazón del sacerdote el eco de la voz y del amor del Redentor. Hablad, además, con confianza, amados hijos, seguros de que el Espíritu de Dios que asiste al Magisterio en el proponer la doctrina, ilumina internamente los corazones de los fieles, invitándolos a prestar su asentimiento. Enseñad a los esposos el camino necesario de la oración, preparadlos a que acudan con frecuencia y con fe a los sacramentos de la Eucaristía y de la Penitencia, sin que se dejen nunca desalentar por su debilidad» (PABLO VI, Enc. Humane vite, 29). Cfr. L. TouZE, El reino de la misericordia en las enseñanzas de los papas Pablo VI, Juan Pablo II, Benedicto XVI y Francisco, Collationes, 3-VI-2016 [goo.gl/ZyHpxw].

22 JuAn PABlo II, Carta al Card. William W. Baum y a los participantes del curso anual sobre el fuero interno organizado por la Penitenciaría Apostólica (22-III-1996), n. 5. 
disposiciones sean mejores, de modo que pueda recibir el perdón: respeta su conciencia pero le recuerda su responsabilidad ante Dios, que es el único que ve el corazón de las personas; le advierte que su relación sexual está en contraste con el Evangelio y con la doctrina de la Iglesia; le exhorta a orar y a esforzarse por llegar gradualmente, con la gracia del Espíritu Santo, a la continencia sexual. Por fin, si el penitente, aun previendo nuevas caídas, muestra cierta disponibilidad a dar pasos en la buena dirección, le da la absolución y le autoriza a acceder a la comunión eucarística siempre que no dé escándalo (ordinariamente en un lugar donde no sea conocido, como hacen también los divorciados vueltos a casar que practican la continencia). En cualquier caso, el sacerdote debe atenerse a las indicaciones dadas por su obispo» ${ }^{23}$.

\section{CUESTIONES INTERPRETATIVAS SUSCITADAS POR AMORIS LAETITIA}

Para interpretar el capítulo octavo es imprescindible hacer una lectura in altum de algunas materias. Entiendo por lectura in altum o en profundidad una interpretación integral, que encaje los textos en sus contextos y despliegue plenamente el contenido de los términos. No quiero decir con esto que la perspectiva del capítulo octavo sea improcedente o arbitraria. Quiero decir que es radical, que subraya con mucho vigor algunas verdades, y en consecuencia, aunque no lo pretenda, otras pueden quedar de hecho oscurecidas o debilitadas ${ }^{24}$. Si quisiéramos establecer un modelo típico de estos subrayados diríamos

${ }^{23}$ E. ANTONELli, Tra regole ed eccezioni, un difficile equilibrio, Settimo Cielo di Sandro Magister, 6VII-2016 [goo.gl/nZ01eW]. El cardenal Antonelli ha publicado más adelante una guía pastoral, que actualmente se encuentra disponible en la web del Consejo Pontificio de la Familia (de un modo ciertamente provisional, porque el consejo pontificio ha desaparecido como tal y sus funciones han pasado a otro dicasterio): E. ANTONELLI, «Amoris Laetitia»: Para su interpretación y aplicación, www.familiam.org, octubre 2016 [goo.gl/kcZBkx].

${ }^{24} \mathrm{O}$ contempladas fuera de contexto. Por ejemplo, en la nota 329 de la exhortación apostólica se lee: «En estas situaciones [irregulares], muchos, conociendo y aceptando la posibilidad de convivir "como hermanos" que la Iglesia les ofrece, destacan que si faltan algunas expresiones de intimidad "puede no raras veces correr riesgos la fidelidad y quedar comprometido el bien de la prole" (Gaudium et spes, 51)». La intimidad conyugal, que en Amoris Laetitia se entiende como un medio para que la unión irregular no se deteriore (afectando indirectamente a la prole), en Gaudium et spes sin embargo se entiende como una exigencia de la fidelidad matrimonial y de la transmisión de la vida: «Cuando la intimidad conyugal se interrumpe, puede no raras veces correr riesgos la fidelidad y quedar comprometido el bien de la prole, porque entonces la educación de los hijos y la fortaleza necesaria para aceptar los que vengan quedan en peligro. Hay quienes se atreven a dar soluciones inmorales a estos problemas; más aún, ni siquiera retroceden ante el homicidio; la Iglesia, sin embargo, recuerda que no puede haber contradicción verdadera entre las leyes divinas de la transmisión obligatoria de la vida y el fomento del genuino amor conyugal». 
que Amoris Laetitia acentúa con gran decisión la misericordia con el pecador. Pero en el mensaje del Señor es también de una evidencia abrumadora la necesidad de la conversión, que en el capítulo octavo queda más en penumbra. Dicho capítulo no está destinado a los frágiles para que se recompongan, sino a la Iglesia para que los reciba. Podríamos decir que quiere convertir a los pastores sin asustar a las ovejas. Y eso exige que una serie de cuestiones sean leídas in altum.

Todas las realidades de salvación se mueven siempre en doble dirección: dar y recibir. Prevalece la recepción, que es acoger la gracia, la misericordia y el perdón, pero también hay que dar. O lo que es lo mismo, para recibir es necesario convertirse. Tal vez el falseamiento más grande, y desde luego el más clásico, es convertir la acción en protagonista, una especie de salvación innecesaria porque uno ya se cree justo. Ése es el punto de referencia, por contraste, de Amoris Laetitia. Con todo, convertir el mensaje de Jesús en mera recepción también sería falso. Ni siquiera el gran error de los fariseos conduce a Jesús a menospreciar la acción. «Hay que hacer esto sin descuidar aquello» (Mt 23,23). La necesidad de la conversión es inapelable en el mensaje del Señor. Nunca hay el mínimo aprecio del pecado, ninguna razón suficiente para esquivar las obligaciones religiosas, la menor excusa para dejar de convertirse.

«Hay que hacer esto sin descuidar aquello». A mi juicio, estas palabras deberían desactivar toda interpretación contradictoria y dialéctica de las actitudes de misericordia y de justicia. No se debería encontrar contradicción entre reconocer el pecado y tratar misericordiosamente al pecador. Como no la hay entre diagnosticar una enfermedad y acoger al enfermo. La elección de una alternativa exigente no lleva consigo el tratamiento inmisericorde del débil. La exigencia cristiana nunca es cruel. No lo digo sólo en el sentido de que una toma de decisión exigente lleve consigo implícitamente misericordia. Lo digo también en el sentido de la misericordia explícita. La exigencia se debe proponer con afecto. $\mathrm{Al}$ fiel que se encuentra en una situación incompatible con los sacramentos no se le abandona a su suerte. Se le hace conocer su bien, se le acompaña en su dolor, y se le pone en camino de salvación. Veamos a continuación una serie de cuestiones que pueden ser leídas in altum.

\subsection{El objeto de la misericordia}

El capítulo octavo de la Exhortación apostólica Amoris Laetitia es sobre todo un canto convencido a la misericordia pastoral. Recogiendo expresio- 
nes de las relationes de los dos sínodos previos, de los documentos anteriores del papa Francisco, o con expresiones nuevas, todo el documento está transido de esta voluntad misericordiosa. Una misericordia que está destinada en primer lugar a acompañar, discernir e integrar la fragilidad. Debido a este planteamiento, en la exhortación apostólica se mira directamente a la misericordia, no al binomio natural justicia/misericordia. La justicia viene citada dos veces de modo ocasional. En la primera ocasión queda disuelta en la misericordia ${ }^{25}$; en la segunda se alerta acerca del peligro de una justicia pura, no misericordiosa ${ }^{26}$. Amoris Laetitia no tiene ninguna voluntad de negar la importancia de la justicia. Simplemente no la tiene como punto de referencia directo. Carlos José Errázuriz ha dedicado unas páginas muy acertadas a explicar precisamente Amoris Laetitia desde la perspectiva de la justicia objetiva ${ }^{27}$.

«La Iglesia debe acompañar con atención y cuidado a sus hijos más frágiles, marcados por el amor herido y extraviado, dándoles de nuevo confianza y esperanza» (AL, 291). «Nadie puede ser condenado para siempre, porque ésa no es la lógica del Evangelio» (AL, 297). Hay que acompañar con misericordia y paciencia haciendo a los frágiles y pecadores «el bien posible» (AL, 308). Porque a veces «"nos comportamos como controladores de la gracia y no como facilitadores. Pero la Iglesia no es una aduana, es la casa paterna donde hay lugar para cada uno con su vida a cuestas" [Evangelii Gaudium, 47]» (AL, 310); «ponemos tantas condiciones a la misericordia que la vaciamos de sentido concreto y de significación real, y ésa es la peor manera de licuar el Evangelio» (AL, 311). Por tanto, los pastores deben tener una actitud que les impida desarrollar «una fría moral de escritorio al hablar sobre los temas más delicados», y les sitúe más bien «en el contexto de un discernimiento pastoral cargado de amor misericordioso, que siempre se inclina a comprender, a perdonar, a acompañar, a esperar, y sobre todo a integrar» (AL, 312).

\footnotetext{
$25 \ll$ Es verdad, por ejemplo, que la misericordia no excluye la justicia y la verdad, pero ante todo tenemos que decir que la misericordia es la plenitud de la justicia y la manifestación más luminosa de la verdad de Dios» (Amoris Laetitia, 311).

${ }^{26}$ «Quizás por escrúpulo, oculto detrás de un gran deseo de fidelidad a la verdad, algunos sacerdotes exigen a los penitentes un propósito de enmienda sin sombra alguna, con lo cual la misericordia se esfuma debajo de la búsqueda de una justicia supuestamente pura» (Amoris Laetitia, 364).

27 C. J. ERrázuriz Mackenna, Matrimonio y justicia objetiva en la comunión eclesial: un aspecto del discernimiento pastoral propiciado por «Amoris laetitia», Ius Canonicum 112 (2016) 731-738.
} 
«Una suerte de suavizante de la ética cristiana» ${ }^{28}$. El cardenal Walter Kasper ha puesto en evidencia la extrema facilidad con la que se confunde la misericordia con un sentimiento amable e inofensivo, sin contenido ninguno de verdad, la misericordia del laissez-faire. Desde luego es una «palabra fácilmente expuesta a los equívocos, como también la palabra amor» ${ }^{29}$. El cardenal Velasio de Paolis explica que no son exactamente lo mismo: «Jesús es el rostro del amor de Dios: es amor cuando perdona, cuando cura, cuando cultiva la amistad, pero también cuando reprende y exige, y cuando condena. Incluso la condena cabe en el amor. La misericordia es un aspecto del amor, el amor que perdona. Dios perdona siempre, porque quiere la salvación de todos nosotros. Pero Dios no puede perdonarnos si nosotros nos ponemos fuera del camino de la salvación y perseveramos allí. En ese caso el amor de Dios se manifiesta en la reprensión y en la corrección, no en la "misericordia", que sería legitimar lo imposible, que llevaría a la muerte y nos confirmaría en ella» ${ }^{30}$.

Decía Tomás de Aquino que «ser misericordioso consiste en tener el corazón mísero por la carga de la miseria de otros: tenemos misericordia de la miseria de los demás cuando la consideramos nuestra. De la nuestra nos dolemos, y procuramos alejarla. Entonces serás verdaderamente misericordioso cuando procures alejar la miseria de los otros» ${ }^{31}$. Ser misericordioso es hacer nuestra la miseria ajena. No para amarla, sino para alejarla. Se ama al miserable, pero no su miseria.

La primera pregunta es: misericordia, ¿¿de qué?; ¿qué miserias debe sentir, sobrellevar y curar la potestad canónica? Sería inconveniente cifrar la misericordia exclusivamente en acciones determinadas o en fragilidades concretas, como si las acciones propias de la misericordia o de la compasión fueran típicas e invariables. En palabras de Tomás de Aquino, en sintonía con toda la tradición canónica, «hay una doble miseria del prójimo. La primera en las cosas temporales; y para ella debemos tener un corazón misericordioso; porque si

${ }^{28}$ W. KASPER, La misericordia. Clave del Evangelio y de la vida cristiana, Sal Terrae, Santander 2013, 143. Kasper dedica unas cuantas páginas a alertar contra la seudomisericordia del laissez-faire (cfr. 143-146).

29 V. DE PAOLIS, I divorziati risposati e i sacramenti dell'Eucarestia e della Penitenza, Inaugurazione del nuovo anno giudiziario del tribunale ecclesiastico regionale dell'Umbria, 27-III-2014 [goo.gl/ kaqC6u].

${ }^{30}$ Ibid.

31 S. Tomás DE Aquino, Super Evangelium Matthaei, 5.2 [traducción propia]. 
alguno tuviese bienes de este mundo y ve a su hermano padecer necesidad, y cierra su corazón, ¿cómo va a permanecer en él la caridad de Dios? (1 Jn 3,17). La segunda miseria es aquella a la que el hombre llega por el pecado: porque, así como la felicidad se encuentra en las obras de virtud, la miseria es propia de los vicios; el pecado hace miserables a los pueblos (Prov 14,34). Por eso, cuando corregimos a los que se equivocan para que vuelvan, somos misericordiosos» ${ }^{32}$.

La primera cosa que salta a la vista cuando se estudia la equidad canónica es que desde los orígenes la equidad canónica ha tenido una preferencia natural para preservar los intereses espirituales y procurar sortear el periculum animae, sobre todo el pecado y lo que favorece el pecado ${ }^{33}$. Es muy característico de la aequitas canonica su interés por tutelar los intereses del alma, su afán de que los fieles se ajusten a la ley divina por encima de exigencias del derecho civil, que les podían poner en peligro de causar o de sufrir escándalo, de faltar a un juramento o a una promesa, de atentar contra la buena fe en los negocios.

Pio Fedele tiene palabras muy explícitas, ya clásicas, sobre esto: «si se quiere entender de verdad qué significado tiene la aequitas canonica en contraste con el significado de la aequitas romana es preciso entender bien el significado que tienen en la economía del ordenamiento canónico las palabras charitas, benignitas, misericordia. Estas palabras, consideradas en relación con el tema del periculum animarum, íntimamente conectado con el de la aequitas, no quieren decir siempre indulgencia, humanidad, perdón. Algunos temas [favorabilitas de la ley penal, obligación de la nuda promissio, principio de que mala fides nocet, etc.] deberían haber puesto sobre aviso para entender en qué sentido se puede hablar, en cuanto a la aequitas canonica, de charitas, de benignitas, de misericordia, pero no se les ha prestado la menor atención. Y entonces se entiende fácilmente que el equívoco sobre la aequitas canonica haya terminado siendo fatal: más que el hecho de considerarla circunscrita al ámbito de la pura técnica hermenéutica, simplemente como un canon de interpretación, como correctivo benigno del rigor iuris, "quejoso recurso de misericordia y de indulgencia para la aplicación de la ley a los casos concretos", como dice Calasso [...], el equívoco fatal se debe al hecho de que al no prestar ninguna aten-

${ }^{32}$ Ibid.

33 Característicos al respecto son los trabajos de Lefebvre: Ch. LeFEBvRE, La doctrine de l'Hostiensis sur la préférence à assurer en droit aux intérêts spirituels, Ephemerides iuris canonici 8 (1952) 2244; «Aequitas canonica» et «periculum animae» dans la doctrine de l'Hostiensis, Ephemerides iuris canonici 8 (1952) 305-321. 
ción al nexo íntimo e inescindible que une la aequitas canonica con el periculum animarum, no se ha captado el significado verdadero que tiene la misericordia siempre que esté en juego la exigencia de evitar este peligro» ${ }^{34}$.

Por tanto, para entender bien la misericordia canónica es importante situar correctamente su objeto. Por ejemplo, en el problema de los divorciados que han contraído nuevo matrimonio civil y desean comulgar hay lugar para un movimiento misericordioso que compadece a un fiel que desea acceder a los sacramentos y no puede hacerlo. Pero en la tradición eclesial tendría poco sentido que la compasión por la exclusión del sacramento fuera jurídicamente predominante sobre la compasión por la situación de pecado en la que ese mismo fiel se encuentra. Se trata siempre de establecer cuál es la misericordia superior y preponderante ${ }^{35}$, o si se quiere la verdadera misericordia, que respeta las prioridades de la aequitas canonica.

Por tanto es importante elegir bien. El movimiento espontáneo de la sensibilidad y de la razón, que advierte la importancia de atender al que sufre una miseria debe ser elegido después por un acto racional prudente, que discierna ${ }^{36}$. En ese acto debe intervenir el punto de vista de la justicia, o dicho de otra manera, las razones justas y buenas. Hay que elegir bien. Y son decisiones históricas, donde siempre hay ambigüedad. Siempre hay partes de bien en una alternativa y en la otra. Además no son siempre alternativas duales. La prudencia lleva a socorrer el mal más dañino para el alma o para el cuerpo después de sopesar las razones. O sea, procurar poner remedio al mal más importante. La misericordia como virtud no es sólo la identificación con el dolor ajeno, sino la disposición de remediarlo.

En la tradición canónica no faltan a veces gritos de alerta frente al legalismo. Pero también se escucha la voz alternativa, el grito de alerta frente a una falsa misericordia dulce. Dentro de esta voz alternativa, que es más fuerte aún que la anterior, tiene un puesto de especial relieve san Ambrosio. En el comentario del salmo 118, san Ambrosio ofrece un pequeño tratado sobre la re-

${ }^{34}$ P. Fedele, Aequitas canonica, Apollinaris 51 (1978) 435-436.

35 Cfr. Ch. LeFEBVRE, «Aequitas canonica» et «periculum animae» dans la doctrine de l'Hostiensis, cir., 318-321.

${ }^{36}$ Así lo entiende Santo Tomás (S. Th., II-II, q. 30, a. 3 in c.) siguiendo en este punto el punto de vista de san Agustín: «¿Y qué es la misericordia, sino una compasión de nuestro corazón por la miseria ajena, que nos obliga y nos empuja a socorrerla, si podemos? Este movimiento sirve a la razón cuando se usa la misericordia de tal modo que quede a salvo la justicia, bien socorriendo al necesitado, bien perdonando al arrepentido. Cicerón, que habló de un modo excelente y elocuente de ella, no dudó en llamarla virtud» (SAn Agustín, De civitate Dei, Lib. 9, cap. 5). 
lación entre misericordia y justicia ${ }^{37}$. Su parte central se dedica a la distinción entre la verdadera y la falsa misericordia. San Ambrosio concentra en sí tres condiciones que le hacen muy pertinente para emitir su opinión en esta materia. En primer lugar, su sensibilidad por los necesitados; su capacidad de apiadarse, podríamos decir; en segundo lugar, su sagacidad descriptiva de las situaciones humanas; y en tercer lugar su altísima autoridad doctrinal. Por todo ello no es lo mismo lo que dice Ambrosio de Milán que lo que diga otro escritor eclesiástico de la antigüedad. Pensemos además que el núcleo central de lo que se expone en este pequeño tratado se encuentra recogido en un canon del Decreto de Graciano.

Veamos algunas de las afirmaciones de san Ambrosio que recoge Graciano en un pasaje de la segunda parte del Decreto (C23 q4 c33): «Hay una misericordia injusta [...] En la misma Iglesia, donde uno debe ser extremadamente misericordioso, hay que ajustarse también al máximo a la regla de la justicia, no vaya a ser que alguien, después de haberse apartado del ambiente de pecado, con una lagrimita, tal vez preparada para el caso, o incluso con mayores manifestaciones de dolor, consiga de la condescendencia del sacerdote una comunión que debería haber pedido a lo largo de mucho tiempo. ¿Es que vamos a provocar el contagio de todos por ser complaciente con un indigno? La indulgencia fácil es un incentivo de pecado» ${ }^{38}$.

En la misma causa recoge Graciano también la dura opinión de Agustín sobre la falsa misericordia: «No pienses que amas a tu siervo cuando no le castigas, o que amas a tu hijo cuando no le sujetas a disciplina, o que amas a tu vecino cuando no le corriges. Eso no es caridad sino indolencia» ${ }^{39}$. Una cuestión más atrás hay dos textos, también atribuidos a san Agustín, que tratan de cuestiones análogas. El primero dice que no debemos apiadarnos del pobre en una mala causa. «No vaya a ser que, actuando sin juicio, seas misericordioso con el pobre en una mala causa, de modo que le ahorres dinero pero le hieras el alma, y encima le haces peor a él porque ve que un hombre bueno le favo-

37 Cfr. Ambrosio de Milán, Opere esegetiche VIII/1, Commento al Salmo CXVIII (Lettere I-XI), Lit. VIII [Eth], 22-30, L. F. Pizzolato (introd., trad., note e indici), Biblioteca Ambrosiana, Milano - Città Nuova Editrice, Roma 1987, 332-341.

38 Ambrosio DE MiLÁn, Opere esegetiche VIII/1, Commento al Salmo CXVIII (Lettere I-XI), Lit. VIII [Eth], 25-26, cit., 334-337 [traducción propia].

39 «Non putes, te tunc amare servum tuum, quando eum non caedis, aut tunc amare filium tuum, quando non das disciplinam, aut tunc amare vicinum tuum, quando non corrigis eum. Non est ista charitas, sed languor» (C23 q5 c36). 
rece» ${ }^{40}$. El segundo exige no apiadarse del pecado sino de la persona: «Cuando decimos estas dos palabras, hombre pecador, no las decimos en vano. Porque es pecador, corrígele, porque es hombre apiádate de él. Y no conseguirás hacer libre al hombre si no hostigas en él al pecador. [...] De modo que a ningún hombre hay que cerrarle la puerta de la misericordia, a ningún pecado hay que consentirle la impunidad» ${ }^{41}$.

Doscientos años más tarde del Decreto de Graciano, pocos días antes de que diese sus primeros pasos el gran cisma de Occidente, le decía santa Catalina de Siena a Urbano VI: «Si se diera justicia sin misericordia, se haría con las tinieblas de la crueldad y más bien sería injusticia que justicia. Por el contrario, la misericordia sin justicia sería en el súbdito como el ungüento sobre una llaga que debe ser cauterizada, ya que poniéndoos sólo el ungüento sin el cauterio la llaga se gangrenaría en vez de sanar. Pero unidas una a la otra, dan vida $\gg^{42}$.

\subsection{El sujeto de la misericordia}

Además del objeto de la misericordia es importante también establecer correctamente el sujeto de la misericordia. Misericordia ¿con quién? Si seguimos la dirección de la Amoris Laetitia, la respuesta es clara: misericordia con los débiles, con los frágiles, con los pecadores. Incluso podríamos decir con los irregulares, en la medida en que esta palabra concita no sólo la miseria personal de la situación de pecado, sino la censura del juicio ajeno y la respuesta contraria del derecho. Todo lo cual es innegable.

Sin embargo, una de las constantes de las soluciones equitativas canónicas es que no es sólo el receptor inmediato de la acción de la potestad quien se puede considerar destinatario de la misericordia. Dicho de otra manera, debe tenerse en cuenta la debida universalización de la misericordia. Cuando la potestad canónica ejercita una acción equitativa mira a la misericordia de

40 «Ne amisso iudicio sis pauperi in mala causa misericors, cuius si parcis saccello, percutis cor, et tanto nequiorem reddis, quanto iustum favere videt sibi» (C23 q4 c34).

41 «Duo ista nomina cum dicimus, homo peccator, non utique frustra dicuntur. Quia peccator est, corripe: et quia homo miserere, nec omnino liberabis hominem, nisi eum persecutus fueris peccatorem. [...] Ita nulli homini claudenda est misericordia, nulli peccato impunitas relaxanda» (C23 q4 c35).

42 Santa Catalina de Siena, Epístola a Urbano VI, junio-julio 1378, en J. Salvador y Conde, Epistolario de Santa Catalina de Siena. Espiritu y doctrina. II. Cartas 169 a 381, San Esteban, Salamanca 1982, Ep. 291, 987. 
todos, del conjunto del pueblo cristiano, no sólo a la misericordia con el sujeto inmediatamente afectado por el hipotético acto compasivo.

Recordemos la carta de san Agustín a Bonifacio contenida en la primera parte del Decreto de Graciano (D. 50 c. 25). Para llevar a cabo un acto de misericordia, san Agustín no apelaba al beneficio del receptor inmediato de la mitigación del rigor iuris (los obispos donatistas), sino a la strages populorum, al estrago que podía ocurrir entre las gentes. Enrique de Segusio, tan enemigo de las subtilitates iuris y del innecesario rigor del derecho cuando estaba en juego un bien espiritual, piensa por ejemplo que no hay lugar para excepciones cuando se trata de facilitar las cosas para el acceso a puestos de relieve eclesial a un simoníaco, a un fornicario o a un perjuro ${ }^{43}$. En todos esos casos deben ser apartados de la comunidad para que no pongan en peligro a los demás. Es decir, para ser misericordiosos con los más débiles. En estos casos los más débiles no son directamente los pecadores sino los que sufren las consecuencias de los pecados.

En los textos clásicos citados en el parágrafo anterior aparecía ya la falsa misericordia que se convierte en incentivo del pecado. Recordemos de nuevo otras palabras de san Ambrosio: «la misericordia con los pecadores [deudores] debe dispensarse de acuerdo con la Palabra de Dios y de acuerdo con la razón. Un médico, si descubre una herida profunda producida por la mordedura de una serpiente, sabe que tiene que cortar la parte infectada de la herida para evitar que se extienda; pero si resulta que las lágrimas del enfermo le retraen de su propósito de cortar y de cauterizar, y se limita a recubrir de ungüentos aquello que debería haber abierto con el cuchillo, ¿no va a ser una misericordia inútil que por evitar el breve dolor de un corte o de una quemadura, se nos corrompa el cuerpo entero y se nos vaya la vida? Por tanto, también el sacerdote, como un buen médico, ha de abrir la herida y sacar el veneno mortal oculto; no taparlo y mantenerlo resguardado de modo que se extienda a todo el cuerpo de la Iglesia. No vaya a ser que por no querer excluir a uno se hagan muchos dignos de exclusión» ${ }^{44}$.

Hoy estamos muy acostumbrados al principio de tolerancia cero en la respuesta a los delitos de graves abusos sexuales. Este principio quiere decir precisamente que en esos casos el bien de la comunidad prevalece, y de qué ma-

${ }^{43}$ Cfr. ibid., 316; G. BrugnOTTO, L'«aequitas canonica». Studio e analisi del concetto negli scritti di Enrico da Susa (Cardinal Ostiense), cit., 176-177.

44 Ambrosio DE MiLÁn, Opere esegetiche VIII/1, Commento al Salmo CXVIII (Lettere I-XI), Lit. VIII [Eth], 26, cit., 336-337. 
nera, sobre el bien del individuo. La dinámica de la tolerancia cero lleva consigo una especie de defensa feroz de la comunidad ante el individuo que comete un determinado crimen. Es una defensa que la Iglesia lleva a cabo para salvar a los propios fieles. Y también para dar un testimonio creíble del profundo dolor que experimenta por el mal causado. Pues bien, en estas circunstancias, la benignidad con el delincuente singular queda en un segundo plano. Importa sobre todo la demostración indiscutible del propio arrepentimiento como institución y la voluntad de buscar el cambio, la conversión de todos.

El día cinco de septiembre de 2016 ha entrado en vigor el Motu proprio Come madre amorevole, del papa Francisco. Comienza con estas palabras: «Como una madre amorosa la Iglesia ama a todos sus hijos. Pero cuida y protege con afecto particular a los más pequeños e indefensos». Se trata de normas penales considerablemente rigurosas para la remoción de obispos que hayan podido ser negligentes en la vigilancia para la protección de niños y adultos vulnerables. Bien se ve que en todos estos casos las ásperas resoluciones jurídicas están dirigidas a evitar el pecado y proteger a los inocentes ${ }^{45}$. Y cualquiera que lo lea se dará cuenta hasta qué punto.

La ampliación del destinatario de la misericordia es sumamente representativa siempre que la autoridad eclesial toma una decisión. No sólo el inmediatamente afectado sufre las consecuencias de ese acto. Toda acción de la autoridad canónica tiene naturalmente un efecto pedagógico y de orientación. Cualquier acción de potestad lo tiene, pero en el caso de la Iglesia está llamado a tenerlo porque es ejercicio de potestad sagrada, es ministerio de salvación, arrastra siempre indicios de la acción de Cristo. Nunca acaba simplemente en el destinatario natural o primario. Cualquiera tiene derecho a mirarla y aprender.

En el caso de los divorciados casados de nuevo, que piden el acceso a los sacramentos sin abandonar su relación, todos los fieles son destinatarios de cualquier decisión pastoral. Sería una ingenuidad pensar que el único afectado por la misericordia de una decisión eclesiástica en esta materia es el fiel que

45 Lo cual no constituye una novedad. En esto san Ambrosio también tiene descripciones magistrales: «si alguno se deja impresionar por las súplicas de los hijos de un ladrón y se deja conmover por las lágrimas de su mujer, y decide absolver a un hombre que tiene todavía dentro de sí el instinto y la voluntad del bandido, ¿no es verdad que liberando a uno que atenta a la vida de muchos se está entregando a la muerte a personas inocentes? Si le respeta la vida, si le quita las cadenas de la cárcel, ¿por qué se le va a evitar también el exilio? ¿Por qué no quitarle, del modo más misericordioso posible, la posibilidad de hacer el mal, ya que no se ha podido doblegar su voluntad?» Ambrosio DE MiLÁN, Opere esegetiche VIII/1, Commento al Salmo CXVIII (Lettere IXI), Lit. VIII [Eth], 25, cit., 335 [traducción propia]. 
solicita la comunión sacramental sin abandonar su unión irregular. Si no ha abandonado su situación objetiva de pecado, todos los fieles aprenderán muchas cosas, en el sentido más neutro de aprender. Aprenderán que hay que tener compasión de los que se encuentran en uniones que contradicen la verdad del matrimonio cristiano; pero «aprenderán» también que es posible un arrepentimiento que no incluya el abandono de la situación de pecado; que es posible recibir la Eucaristía aunque su condición de vida contradiga objetivamente la unión de amor entre Cristo y la Iglesia; que el Señor no siempre quiere para sus fieles el matrimonio indisoluble, sino que puede aprobar también otras uniones. Si preferimos decirlo así, todo el pueblo cristiano necesita ser protegido del pecado y del escándalo.

Todos sabemos que la doctrina y la praxis pastoral son dos cosas distintas. Lo que debe preocuparnos es que sean coherentes. Sería malo considerar aceptable una incoherencia práctica entre la doctrina y la realidad. $\mathrm{O}$ lo que es lo mismo, no considerar deficiente una realidad pastoral precisamente por ser realidad pastoral. La máxima misericordia con la realidad pastoral consiste en tratar sus deficiencias como deficiencias. Un gran riesgo de la pastoral de la Iglesia sería establecer una disciplina suave para los débiles y unos ideales santos para los fuertes.

Claro está que todo esto no es fácil. Los pastores siempre tendrán delante un clamor según el cual la Iglesia debería demoler sus paradigmas del pasado, salir de sus seguridades artificiales, sentir con su verdadero prójimo (no con el de los viejos tiempos), evadirse de las ataduras esclavizantes de una sociedad que ella mismo creó pero que ya no existe, curarse de un soberbio perfeccionismo, y tantas otras cosas. Hay que aprender a escuchar todo esto y también ayudar a pensar mejor las metáforas. Porque cuando alguien debe caracterizar una realidad cristiana como el matrimonio, su primera obligación es buscar imágenes en las que comparezca Dios creador, redentor y santificador; es decir, imágenes en las que se revele, junto con la deficiencia humana, la seguridad del designio divino y la confianza en la gracia.

\subsection{La imputabilidad del pecado}

El capítulo octavo de Amoris Laetitia tiene desde el primer momento un gran interés en discernir las situaciones de los divorciados vueltos a casar. «Los divorciados en nueva unión, por ejemplo, pueden encontrarse en situaciones muy diferentes, que no han de ser catalogadas o encerradas en afirmaciones de- 
masiado rígidas sin dejar lugar a un adecuado discernimiento personal y pastoral» (AL, 298). «El discernimiento puede reconocer que en una situación particular no hay culpa grave» (AL, 300, nt 336). Dedica todo un apartado (cfr. AL, 301-303) a las circunstancias atenuantes de las situaciones irregulares. Más adelante la exhortación apostólica explica la funcionalidad pastoral de esas circunstancias: «A causa de los condicionamientos o factores atenuantes, es posible que, en medio de una situación objetiva de pecado - que no sea subjetivamente culpable o que no lo sea de modo pleno-se pueda vivir en gracia de Dios [...]. Por creer que todo es blanco o negro a veces cerramos el camino de la gracia y del crecimiento, y desalentamos caminos de santificación que dan gloria a Dios» (AL, 305). El discernimiento pastoral puede descubrir atenuantes capaces de hacer que la vida del que se encuentra en situación irregular sea, en medio de los límites, una vida que dé gloria a Dios. Tal vez uno de los puntos que más ha sorprendido a los comentaristas de la Amoris Laetitia ha sido la extremada eficacia funcional de las circunstancias atenuantes, capaces de convertir una situación de pecado en una situación de gracia.

En orden al elenco de los atenuantes, Amoris Laetitia remite en cinco ocasiones a una seriación más o menos indeterminada. Casi siempre cita documentos de prestigio, en pasajes generales o introductorios. Así por ejemplo el Catecismo de la Iglesia Católica: «la ignorancia, la inadvertencia, la violencia, el temor, los hábitos, los afectos desordenados y otros factores psíquicos o sociales» ${ }^{46}$, o también: «la inmadurez afectiva, la fuerza de los hábitos contraídos, el estado de angustia u otros factores psíquicos o sociales» ${ }^{47}$; un texto de la Exhort. ap. Reconciliatio et paenitentia de Juan Pablo II: «situaciones muy complejas y oscuras bajo el aspecto psicológico, que influyen en la imputabilidad subjetiva del pecador» ${ }^{48}$; un texto de la Declaración de la Congregación para la doctrina de la fe sobre la eutanasia: «el dolor prolongado e insoportable, razones de tipo afectivo u otros motivos diversos» ${ }^{49}$; y un texto de la Relatio Synodi de 2015: «factores que limitan la capacidad de decisión» ${ }^{50}$. Estos textos tienen todas las ventajas y todos los inconvenientes de los textos generales.

\footnotetext{
${ }^{46}$ Catecismo de la Iglesia Católica, 1735 (AL, 302).

${ }^{47}$ Ibid., 2352 (AL, 302).

48 Exhort. ap. Reconciliatio et paenitentia (2-XII-1984) 17 [AAS 77 (1985) 223] (AL, 302).

49 CONGRegación PARA La DoctRINA DE LA Fe, Declaración Iura et bona, sobre la eutanasia (5-V1980), II: AAS 72 (1980) 546 (AL, 302, nt 344). Amoris Laetitia sin embargo no cita este texto más que implícitamente.

${ }^{50}$ Relatio finalis Synodi 2015, 51 (AL, 301).
} 
Pueden ser circunstancias atenuantes, pero en todo caso conviene leerlos en el contexto global de cada documento ${ }^{51}$.

Antes de nada hay que decir algo que afecta a la fuerza argumentativa que pueda tener el sistema de los atenuantes de la moralidad en la cuestión del acceso a los sacramentos. Cuando la Iglesia ha prohibido la comunión eucarística de los que se encuentran en situación objetiva de pecado (adulterio) no ha invocado la certeza que ella posee de que esas personas no están en gracia de Dios. Alega otro tipo de certeza objetiva, en concreto que «su estado y situación de vida contradicen la unión de amor entre Cristo y la Iglesia, significada y actualizada en la Eucaristía ${ }^{52}$. Por todo ello la disputa de la atenuación del pecado tiene una importancia secundaria en orden a justificar la administración de los sacramentos a las personas en situación irregular. De cualquier manera es una cuestión que no se puede obviar si se examina Amoris Laetitia.

El régimen que deban seguir estos atenuantes no es fácil de determinar. Los eximentes completos de pecado, como la ignorancia plena, la violencia, o la coacción moral irresistible, no son supuestos que merezca la pena considerar porque no son planteables en la práctica en casos como los que nos ocupan. Para establecer atenuantes que tengan efectos verdaderos en esta materia hay que tener en cuenta algunas cuestiones.

Se hace preciso en primer lugar distinguir entre atenuantes y condicionantes del acto moral. Todo acto humano está condicionado. No existen actos sin contaminación. Esos condicionantes no suponen necesariamente una mitigación de la responsabilidad. A veces la agravan. Los condicionantes más típicos de los actos son las virtudes y los vicios. Las virtudes ayudan a obrar bien,

${ }^{51}$ En el ámbito de la imputabilidad del pecado existen seis textos citados por Amoris Laetitia que merecen una lectura integral, in altum. Aunque el valor del texto en sí mismo es innegable, si se lleva a cabo dicha lectura (conociendo el contexto en el que son citados, las formulaciones textuales precedentes o subsiguientes, el resto de las referencias en pasajes paralelos, etc.) ofrecen una información mucho más amplia y realista. Esos textos son: JUAN PABLo II, Exhort. ap. Familiaris Consortio (22-XI-1981) 33 (AL, 301); JuAN PABLO II, Exhort. ap. Reconciliatio et paenitentia (2-XII-1984) 17 (AL, 302); JuAn PABlo II Catecismo de la Iglesia Católica (11-X-1992) 1735, 2352 (AL, 302); SANTo Tomás De Aquino, S. Th., I-II, q. 65, a. 3, ad 2-3 (AL, 301); CongreGACIÓN PARA LA Doctrina DE LA FE, Decl. Iura et bona, sobre la eutanasia (5-V-1980), II (AL, 302); Pontificio Consejo para los Textos Legislativos, Declaración sobre la admisibilidad a la sagrada comunión de los divorciados que se ban vuelto a casar (24-VI-2000) 2 (AL, 302).

52 JuAn PABLO II, Familiaris consortio, 84; BENEDiCTO XVI, Sacramentum caritatis, 29. Cfr. para una explicación específica y directa sobre este particular, PONTIFICIO CONSEJO PARA LOS TeXTOS Legislativos, Declaración sobre la admisibilidad a la sagrada comunión de los divorciados que se han vuelto a casar, 24-VI-2000. 
los vicios dificultan la acción buena. Un acto dificultado por una costumbre viciosa, por un acostumbramiento en el mal, no es menos responsable. Más bien agrava la responsabilidad moral. Algo semejante podemos decir de la acción virtuosa. Cuando se obra bien ayudados por la virtud, el acto no pierde bondad sino que la manifiesta y la acrecienta. Amoris Laetitia presenta frecuentemente la situación de dificultad como un límite de la acción: «una gran dificultad para comprender los valores inherentes a la norma» (AL, 301); «grandes dificultades para actuar en modo diverso» (AL, 302); «dificultades para vivir plenamente la ley divina» (AL, 306), y otros muchos pasajes similares. Es claro que estas dificultades no constituyen de suyo atenuantes de la acción. Lo serán quizá alguna vez, pero muchas otras serán un condicionante profundamente voluntario. Esto tiene especial relieve en las dificultades para comprender. Una dificultad para comprender que conduce deliberadamente a una efectiva falta de comprensión es una ceguera voluntaria ${ }^{53}$.

¿Qué valor se debe atribuir a la interioridad del que se encuentra en la situación irregular? Es posible, como expone Amoris Laetitia, que quien se encuentra en una situación de pecado esté en gracia de Dios. Se ha hecho ver sin embargo que la intimidad auténtica, la verdad absoluta del alma, no se hace patente ni a uno mismo. Sobra decir por lo tanto que el discernimiento no puede pretender escudriñar hasta la certeza la situación interior de las almas. Es más, la primera misión del discernimiento es valorar con corrección las acciones exteriores y las expresiones (también exteriores) que el sujeto emplea para valorar sus obras. No quiero decir con esto, claro está, que toda comunicación acabe ahí. Pero la intimidad del sujeto no es sinónimo de verdad. Merece un respeto absoluto, pero puede estar confundida, desorientada, mezclada. Por eso la primera regla del discernimiento es la humildad para no suplantar la verdad del acto por verdades de apreciación subjetiva. Y por supuesto, no suplantar la ley de Dios por la ley del hombre. Sobre esto se han hecho muchos comentarios que ayudan a entender la verdadera dirección de Amoris Laetitia ${ }^{54}$. Hace pocos meses decía el cardenal Gerhard Ludwig Müller

${ }^{53}$ Con especial vigor se expresa en este sentido N. MARTínEZ, Algunas observaciones sobre la imputabilidad en «Amoris Laetitia», 9-IV-2016 [goo.gl/lhrI77]).

${ }^{54}$ Cfr. por ejemplo, A. SCHNEIDER, Il paradosso delle interpretazioni contraddittorie di «Amoris laetitia», Veri Catholici, 24-IV-2016 [goo.gl/DUh4Zk]; J. SEIFERT, Die Freude der Liebe: Freuden, Betrübnisse und Hoffnungen, Katholisches.info, 3-VIII-2016 [goo.gl/bg7vTP]; J. MERECKI, Fedeltà troppo creativa diventa infedeltà, Settimo Cielo di Sandro Magister, 4-VIII-2016 [goo.gl/tzZ87J]; A. Gracián, Inconveniencias eclesiales, VIII, InfoCatólica, 16-V-2016 [goo.gl/LxoR0C], [goo.gl/ 
que «algunos han interpretado que el Papa, al decir que se tengan más en cuenta las circunstancias atenuantes, pediría que el discernimiento se basara en ellas, como si éste consistiera en escrutar si la persona es o no culpable subjetivamente. Ahora bien, este discernimiento sería, en último término imposible, pues sólo Dios escruta los corazones. Además, la economía de los sacramentos es una economía de signos visibles, no de disposiciones interiores o de culpabilidad subjetiva. Una privatización de la economía sacramental no sería ciertamente católica ${ }^{55}$.

A mi parecer sin embargo, el problema más difícil que plantea la imputabilidad en Amoris Laetitia es lo que podríamos llamar la valoración de las circunstancias atenuantes en el tiempo. Como ha explicado muy bien Christian Brugger, en el trabajo tal vez más cuidadoso acerca de este punto, una cosa es la culpabilidad retrospectiva y otra la culpabilidad prospectiva ${ }^{56}$. Un pastor puede descubrir en un penitente, o en un fiel que se sujeta a su discernimiento, que ha existido un atenuante que limita su comprensión de la vida cristiana. El verdadero problema moral se plantea cuando ese pastor aconseja mantener el límite o la situación objetiva de pecado para el futuro. Mantener la ignorancia, dar crédito al error, dar por buena una dificultad de comprensión, todo eso contrasta con la actitud de conversión y no es aceptable ${ }^{57}$. Robert Gahl, en polémica con Rocco Buttiglione, reconoce que «tiene razón cuando dice que algunos pecados pasados pueden no ser subjetivamente imputables, pero su sugerencia de que el confesor puede dar al penitente un "pass" gratuito para dichos pecados en el futuro no puede conciliarse con la tradición, que sostiene que los pecadores habituales deben arrepentirse para ser perdonados y que su arrepentimiento debe incluir un firme propósito de enmienda [...]. Jesús dijo a la mujer sorprendida en adulterio: "Vete y no peques más" (Jn 8,11). Los buenos confesores saben guiar

kDAHBI]; G. WoOdall, «Amoris laetitia», conciencia y discernimiento, CatolicosOn-line.org [goo.gl/tq7wTr]; A. LIVI, Tante affermazioni che vanno chiarite, La nuova Bussola Quotidiana, 13IV-2016 [goo.gl/4pNiJ2]; E. C. BRUGGER, Five serious problems with Chapter 8 of «Amoris Laetitia», Catholic World Report, 22-IV-2016 [goo.gl/iUj0Qh].

55 G. L. MÜLLER, ¿Qué podemos esperar de la familia?, 4-V-2016 [goo.gl/D5Vqad].

${ }^{56}$ Cfr. E. C. Brugger, Five serious problems with Chapter 8 of «Amoris Laetitia», Catholic World Report, 22-IV-2016 [goo.gl/iUj0Qh].

57 «En el caso de que una persona realizara actos morales objetivamente graves con plena conciencia, con salud mental, con decisión libre, y tuviera el propósito de repetir dicho acto en el futuro, sería imposible aplicar el principio de la no imputabilidad de la culpa por razón de circunstancias atenuantes» (A. SCHNEIDER, Il paradosso delle interpretazioni contraddittorie di «Amoris laetitia», Veri Catholici, 24-IV-2016 [goo.gl/DUh4Zk]). 
a sus penitentes hacia el pleno arrepentimiento, ayudándoles a reflexionar sobre lo que pueden hacer para liberarse de una situación difícil o de un dilema aparente» ${ }^{58}$.

\subsection{Los actos intrinsecamente desordenados}

La presentación de los atenuantes de la imputabilidad ha desatado también la dinámica (y la polémica) de los actos intrínsecamente desordenados. Amoris Laetitia emplea, si se me permite decirlo así, expresiones rigurosas con el rigor pero como es lógico jamás niega este principio de la moral católica. Veamos un pequeño muestrario de estas expresiones gráficas: «las consecuencias o efectos de una norma no necesariamente deben ser siempre las mismas» (AL, 300); «es mezquino detenerse sólo a considerar si el obrar de una persona responde o no a una ley» (AL, 304); «un pastor no puede sentirse satisfecho sólo aplicando leyes morales a quienes viven en situaciones irregulares, como si fueran piedras que se lanzan sobre la vida de las personas» (AL, 305); «es posible que, en medio de una situación objetiva de pecado [...] se pueda vivir en gracia de Dios» (AL, 305); «por creer que todo es blanco o negro a veces cerramos el camino de la gracia» (AL, 305). Este tipo de expresiones no compromete sin embargo lo que Juan Pablo II estableció en Veritatis Splen$d o r^{59}$, siguiendo por lo demás la tradición clásica de la moral católica: el rechazo de cualquier tesis que niegue la posibilidad de calificar las acciones como malas por su objeto, y la seguridad de que existen actos configurados como no ordenables al fin último, y por lo tanto intrínsecamente malos (por ejemplo el

${ }^{58}$ R. A. GAHL, JR., Guarire attraverso il pentimento. Una risposta alla lettura di Rocco Buttiglione della «Amoris laetitia», Settimo Cielo di Sandro Magister, 2-VIII-2016 [goo.gl/qxsLJN]. Cfr. C. A. CaSANOva, Una risposta all'interpretazione di «Amoris Laetitia» fatta di Rocco Buttiglione, Settimo Cielo di Sandro Magister, 20-X-2016 [goo.gl/uVf1Z].

59 «Así pues, hay que rechazar la tesis, característica de las teorías teleológicas y proporcionalistas, según la cual sería imposible calificar como moralmente mala según su especie -su "objeto"-la elección deliberada de algunos comportamientos o actos determinados prescindiendo de la intención por la que la elección es hecha o de la totalidad de las consecuencias previsibles de aquel acto para todas las personas interesadas. El elemento primario y decisivo para el juicio moral es el objeto del acto humano, el cual decide sobre su "ordenabilidad" al bien y al fin último que es Dios. [...] Ahora bien, la razón testimonia que existen objetos del acto humano que se configuran como no-ordenables a Dios, porque contradicen radicalmente el bien de la persona, creada a su imagen. Son los actos que, en la tradición moral de la Iglesia, han sido denominados intrínsecamente malos ("intrinsece malum"): lo son siempre y por sí mismos, es decir, por su objeto, independientemente de las ulteriores intenciones de quien actúa, y de las circunstancias» (JUAN PABLO II, Enc. Veritatis Splendor, 6-VIII1993, nn. 79-80). 
adulterio). El problema se ha recrudecido en parte porque algunos autores representativos, como el cardenal Cristoph Schönborn o Antonio Spadaro, han hablado en tono crítico de los extremos viciosos a los que puede llevar una teología moral de los actos intrínsecamente buenos o malos. La «obsesión del intrinsece malum» habría «empobrecido el debate» y podría «aniquilar» la articulación del acto moral, según el cardenal Schönborn ${ }^{60}$. Por otra parte otros autores, extremadamente representativos también (los cardenales Brandmüller, Burke, Cafarra y Meisner ${ }^{61}$ ), han pedido al Papa la respuesta auténtica, simple y decretoria, a cinco dubia, tres de las cuales están en relación directa con Veritatis Splendor.

\subsection{Los supuestos generales y el realismo pastoral}

Amoris Laetitia subraya con fuerza el carácter general de las normas, en contraste con la situación singular de las personas. Es innecesario decir que se trata de una apreciación completamente correcta. Las normas «en su formulación no pueden abarcar absolutamente todas las situaciones particulares» (AL, 304). Por otra parte no cabe duda de que la norma «no basta para discernir y asegurar una plena fidelidad a Dios en la existencia concreta de un ser humano» (AL, 304).

El documento pondera constantemente el valor de las situaciones individuales ${ }^{62}$. Son muy diversas, difíciles de ser categorizadas, a veces «rompen todos los esquemas» (AL, 37). En Amoris Laetitia, «la innumerable diversidad de situaciones concretas» impide que se formule «una normativa general [...] aplicable a todos los casos» (AL, 300). La realidad personal constituiría una realidad singular, inapresable, inefable, no contenible en las normas. En palabras del cardenal Ricardo Blázquez, «un santuario que nadie puede invadir» ${ }^{63}$.

${ }^{60}$ Cfr. Ch. SChÖnboRn, Matrimonio e conversione pastorale. Intervista di Antonio Spadaro al cardinale Cristoph Schönborn, La Civiltà Cattolica, n. 3966, 26-IX-2015 [goo.gl/OxqnTq]; A. SpaDARo, Struttura e significato dell'Esortazione apostolica post-sinodale di papa Francesco, La Civiltà Cattolica, n. 3980, 23-IV-2016, 120, nt 11.

${ }^{61}$ Cfr. Card. W. Brandmüller - Card. R. L. Burke - Card. C. Caffarra - Card. J. Meisner, Fare chiarezza. Nodi irrisolti di «Amoris Laetitia». Un appello, chiesa.espresso.repubblica.it, 14-XI2016 [goo.gl/cSq1gF].

${ }^{62}$ El lenguaje de la exhortación apostólica ha sido caracterizado como «situacional»: A. GRACIÁN, Inconveniencias eclesiales IV. Uso de lenguaje situacional en «Amoris Laetitia», I. Puntos 291 a 300, InfoCatólica, 25-IV-2016 [goo.gl/gLdGFf].

${ }^{63}$ R. BlázQuez PéreZ, Nell'Amoris Laetitia. Il magistero della gioia, L'Osservatore Romano, 15-IV2016. 
Como resultado de todo ello, «las consecuencias o efectos de una norma no necesariamente deben ser siempre las mismas» (AL, 300). Dependerían del grado de responsabilidad de cada uno.

De modo inverso a las normas generales, el discernimiento práctico se haría cargo de las situaciones singulares. Sería «preferible» (AL, 304, nt 348). O lo que es lo mismo, resultaría más realista, más lúcido y perspicaz. Sería capaz de desentrañar la verdad de cada situación, sin patrones ajenos. En consecuencia, prevalecería en ocasiones sobre la norma general. La conciencia «puede reconocer no sólo que una situación no responde objetivamente a la propuesta general del Evangelio. También puede reconocer con sinceridad y honestidad aquello que, por ahora, es la respuesta generosa que se puede ofrecer a Dios» (AL, 303). Este discernimiento, ordinariamente ejercido por el ministerio pastoral, podría ser también la mirada de cada uno sobre su conciencia. Los propios fieles «muchas veces responden lo mejor posible al Evangelio en medio de sus límites y pueden desarrollar su propio discernimiento» (AL, 37). Amoris Laetitia quiere insuflar «un nuevo aliento a un responsable discernimiento personal y pastoral de los casos particulares» (AL, 300).

A las normas les correspondería un lugar de honor, en el sentido de que establecen un grado de excelencia formal. «Aquello que forma parte de un discernimiento práctico ante una situación particular no puede ser elevado a la categoría de una norma» (AL, 304). Pero este grado formal sería sobre todo de carácter orientativo y estimulante. El riesgo, el gran peligro frente al cual alerta Amoris Laetitia, sería emplear las normas como si fueran instrumentos absolutos de medida o de juicio. Detenerse a considerar solamente si el obrar de una persona responde o no a una ley o norma general «es mezquino» (AL, 304). Los juicios inmediatos basados en normas son considerados como piedras lanzadas al que se encuentra en situación de pecado ${ }^{64}$. Detrás está in-

${ }^{64}$ Me parecen de interés estas palabras de Velasio de Paolis que distinguen muy correctamente entre la valoración y la condena: «Spesso, e giustamente, si dice che noi non siamo chiamati a condannare le persone; il giudizio infatti appartiene a Dio. Ma una cosa è condannare un'altra è valutare moralmente una situazione, per distinguere ciò che è bene e ciò che è male; esaminare se essa risponde al progetto di Dio sull'uomo. Questa valutazione è doverosa. Davanti alle diverse situazioni della vita, come quella dei divorziati risposati, si può e si deve dire che non dobbiamo condannare, ma aiutare; però non possiamo limitarci a non condannare. Siamo chiamati a valutare quella situazione alla luce della fede e del progetto di Dio e del bene della famiglia, delle persone coinvolte, e soprattutto della legge di Dio e del suo disegno di amore. Altrimenti corriamo il rischio di non essere più in grado di apprezzare la legge di Dio; anzi di considerarla quasi un male, dal momento che facciamo derivare tutto il male da una legge. In un certo modo di presentare le cose verrebbe quasi da dire che se non ci fosse quella legge della indissolubilità 
dudablemente la imagen de la mujer pecadora que sufre el riesgo inmediato de la lapidación. «Un pastor no puede sentirse satisfecho sólo aplicando leyes morales a quienes viven en situaciones "irregulares", como si fueran piedras que se lanzan sobre la vida de las personas» (AL, 305). La Iglesia debe evitar «imponerles una serie de normas como si fueran una roca» (AL, 49). «Estamos llamados a formar las conciencias, pero no a pretender sustituirlas» (AL, 37). No se puede convertir el Evangelio en una receta normativa o doctrinal, «convertirlo en "piedras muertas para lanzarlas contra los demás" [Francisco, Discurso de clausura del Sinodo, 24-X-2015]» (AL, 49).

Hasta aquí la relación entre normas generales y situaciones singulares tal y como es descrita en Amoris Laetitia. ¿Qué podemos decir de esta descripción? Entender bien las propuestas de la exhortación apostólica precisa a mi parecer tres comentarios.

\subsubsection{Tipología de las normas}

No es oportuno entender las normas como realidades unívocas e indiferenciadas. Las normas pueden ser morales o jurídicas, aunque frecuentemente las normas jurídicas formalicen contenidos morales. Pueden ser también normas de derecho natural o de derecho positivo. Pueden ser de derecho divino o de derecho humano. Comprendo que son cuestiones muy básicas, pero me parece imprescindible distinguir. El derecho natural es derecho divino, la participación de la ley eterna de Dios creador en la razón humana. El derecho divino puede tener también carácter positivo. Entendemos por derecho divino positivo aquello que conocemos con certeza como querer de Dios en las fuentes de la revelación sobrenatural, siempre que concierna a realidades de la vida de la Iglesia. Cuando nos encontramos en el ámbito de la ley divina, sea natural o positiva, la doctrina católica (moral y jurídica) no ha admitido nunca las excepciones. Para esto sin duda hace falta cobrar conciencia de que aquello pertenece al designio trinitario sobre la Iglesia, sobre el hombre o sobre el mundo, lo cual no siempre ha sido una tarea fácil e inmediata. Una vez cobrada esa conciencia, sin embargo, hay continuidad y plenitud, porque se entiende que lo contrario no puede dar gloria a Dios ni salvar al hombre.

del matrimonio staremmo meglio. Aberrazione che mette in luce le storture del nostro modo di pensare e ragionare» (V. DE PAOLIS, I divorziati risposati e i sacramenti dell'Eucarestia e della Penitenza, cit., $27-\mathrm{III}-2014$ [goo.gl/kaqC6u]. 
Benedicto XVI, en su famoso discurso a la Rota de 2012 fue extremadamente crítico frente al positivismo, y también frente a la mera interpretación gramatical de las leyes canónicas positivas. Pero eso exige precisamente un respeto muy profundo a la ley divina. Los textos legales «deben interpretarse [...] a la luz de la realidad regulada, la cual contiene siempre un núcleo de derecho natural y divino positivo, con el que debe estar en armonía cada norma a fin de que sea racional y verdaderamente jurídica ${ }^{65}$.

\subsubsection{Funcionalidad de las normas}

Me parece muy importante entender bien la naturaleza, y en consecuencia la funcionalidad, de las normas generales. No es infrecuente que cuando se trata de normas jurídicas (o morales) se mezcle una idea antijurídica difusa que entiende lo normativo como disciplinario, y lo disciplinario como impositivo. Las normas jurídicas no son sólo disciplinarias. El derecho normativo sólo de vez en cuando impone modos de obrar. «Muy frecuentemente hace otras cosas: reconoce derechos, otorga garantías, da a conocer los instrumentos que emplea, diseña estructuras, protege a los individuos o a las asociaciones, valora los actos, prevé hipotéticos problemas en los que cualquiera podría encontrarse. En fin, las normas describen la vida. Entender el sistema normativo como la ordenanza de un desfile militar es muy inconveniente. Cualquier persona, incluso los que tienen una mentalidad que desprecia lo jurídico, se sienten más seguros en un Estado de derecho que en un Estado que no lo sea, porque perciben que las leyes no sólo imponen, sino que sobre todo protegen ${ }^{66}$.

Hay que hacer otra advertencia muy importante. En estos momentos existe una especie de acuerdo tácito de que la grandeza del hombre está en su singularidad. La generalidad sería un añadido impuesto, a veces artificial. Cada uno debe ser cada uno. Cada situación humana ha de ser entendida como algo propio y medido por su propia regla. Sin embargo, la grandeza del hombre está en su condición humana, que cada uno debe «hacer propia». Es importante entender que la generalidad dignifica. Cuanto más asume cada uno la generalidad, se descubre mejor a sí mismo, encuentra la medida más exacta de su propia alma, vive con más profundidad y más gozo. Esto lógica-

${ }^{65}$ Benedicto XVI, Alocución a la Rota Romana, 21-I-2012 (AAS 104 [2012] 105-106).

${ }^{66} \mathrm{~J}$. OTADUY, Giuridicità e prospettiva antigiuridica nell'interpretazione e ricezione del Vaticano II, en E. BAURA (a cura di), Diritto e norma nella liturgia, Giuffrè, Milano 2016, 64-65 [traducción propia]. 
mente se evidencia con mucho más realismo en el caso de las normas de derecho divino, pero debería ocurrir también con las normas del derecho humano, siempre que sean razonables. Nadie lo duda cuando lo que se proclaman son los derechos del hombre. Tampoco se habría de dudar si lo que se proclaman son los deberes del hombre, o los deberes del cristiano.

La experiencia nos dice a cada uno que la tentación de salirse de la regla conduce fácilmente hacia una cierta pérdida de dignidad. A veces se produce una confusión entre persona humana y situación humana. Cada una de las personas humanas singulares es sagrada, pero cada una de las situaciones en las que se encuentran esas personas humanas no es sagrada. A mi juicio no sería adecuado entender que el carácter sagrado de cada hombre y de cada mujer arrastra consigo sagradas excepciones. Cada hombre vale toda la sangre de Cristo y precisamente por eso la llamada a la dignidad y a la santidad es universal.

El horizonte del capítulo octavo de Amoris Laetitia son los frágiles, no los santos; las ovejas descarriadas, no las ovejas fieles. No se puede perder de vista ese horizonte, que como es lógico cabe dentro de la ley divina ${ }^{67}$. Dicho de otro modo, curar a un frágil exige un deseo verdadero de curación, una conversión del corazón. Todos los corazones, fracturados o íntegros, están llamados a la plenitud de la gracia, a la plenitud de la caridad, a la plenitud del querer divino. Al menos al sincero deseo de él.

\subsubsection{Aplicación de las normas}

El lenguaje de Amoris Laetitia se entiende mejor si se orienta a alejar al pastor de la crueldad que a alejarlo de la aplicación del derecho. La metáfora de la lapidación, tan viva a lo largo de todo el documento, tiene sentido sobre todo por el modo en que los descubridores del flagrante delito de adulterio acusan a la víctima. La ponen en evidencia, la desprecian y la amenazan con piedras en las manos. En realidad el resultado de la escena no es que la delincuente resulte eximida de la norma, y en consecuencia del pecado, sino que el

\footnotetext{
${ }^{67}$ «No hay inconveniente alguno en afirmar la primacía de la misericordia de Dios en la vida cristiana, como siempre hemos afirmado el primado de la gracia. Ahora bien, ese primado no nos permite olvidar que los mandamientos son una exigencia para la salvación cristiana, como lo veíamos a propósito de las palabras de Cristo y de 1 Corintios 6,9-10. No hay salvación sin el cumplimiento de las exigencias morales graves. $\mathrm{Y}$ el cumplimiento de nuestros deberes morales es también causa de nuestra salvación. Olvidar esto significa deformar el cristianismo. Nosotros, cumpliendo los mandamientos, nos salvamos» (J. A. SAYÉs, La misericordia de Dios en la «Amoris laetitia», CatólicosOn-line.org [goo.gl/0rJjg0]).
} 
pecado resulta perdonado porque hay dolor y arrepentimiento verdadero («vete y no peques en adelante»). La aplicación de una misma norma puede ser el impacto de una piedra o la unción de un bálsamo. En el caso de Cristo con la adúltera, la aplicación de la norma se hace con una delicadeza sorprendente y con una eficacia de conversión sorprendente también. No existe el menor indicio de aceptación del mal. Por eso, Amoris Laetitia puede entenderse mejor si se percibe como un modo de evitar toda crueldad en la aplicación de la justicia ${ }^{68}$.

Hay diversos pasajes de Amoris Laetitia sobre reglas generales y situaciones singulares o particulares en que se citan textos de autoridad que merecen una interpretación in altum o integral ${ }^{69}$. Centraremos la atención tan sólo en un texto que el papa Francisco invoca de un modo perentorio para la relación entre las normas generales y las situaciones singulares: «ruego encarecidamente que recordemos siempre algo que enseña santo Tomás de Aquino» $(\mathrm{AL}, 304)^{70}$. Es el cuerpo de un artículo de la Summa Theologiae: «aunque en los principios generales haya necesidad, cuanto más se afrontan las cosas particulares, tanta más indeterminación hay [...] En el ámbito de la acción, la verdad o la rectitud práctica no son lo mismo en todas las aplicaciones particulares, sino solamente en los principios generales; y en aquellos para los cuales la rectitud es idéntica en las propias acciones, ésta no es igualmente conocida por todos [...] Cuanto más se desciende a lo particular, tanto más aumenta la indeterminación» ${ }^{71}$.

${ }^{68}$ No se puede decir propiamente que las normas del derecho divino se aplican. Es verdad que en ocasiones un pastor debe declarar (ordinariamente en el fuero sacramental) cuál es el contenido de la ley divina. Pero evidentemente el pastor no está aplicando una regla externa a una situación que hasta ese momento era neutra e inocente. Lo que hace es declarar la realidad que ya existe. No tiene nada de constitutivo. No añade ninguna vis obligandi nueva.

${ }^{69}$ Pueden verse estos textos: BenEdICTO XVI, Diálogo con el Papa. VII Encuentro Mundial de las Familias en Milán (2 junio 2012) [goo.gl/hj7hlu] (AL, 298); COMISIÓN TEOLÓGICA INTERNACIONAL, Alla ricerca di un'etica universale: nuovo sguardo sulla legge naturale, 59 vatican.va [goo.gl/3NkdP7] = La Civiltà Cattolica II, 3816 [20 giugno 2009] 533-539 (AL, 305); JUAN PABLO II, Carta a la Secretaria General de la Conferencia internacional de la Organización de Naciones Unidas sobre la población y el desarrollo (18-III-1994), L'Osservatore Romano, ed. española, 8-IV-1994, 11 (AL, 167).

${ }^{70}$ Según algunos ha sido precisamente la doctrina tomasiana la que ha dado el tono nuevo y distinto de Amoris Laetitia: el paso de la pura razón a la prudencia, de lo universal a lo particular, de la ética legal a la moral de virtudes: R. GUERRA LóPEZ, Fedeltà creativa. Dalla riflessione di Karol Wojtyla all'esortazione «Amoris laetitia», L'Osservatore Romano, 22-VII-2016 [goo.gl/ORY9XS]; W. KASPER, «Amoris laetitia»: Bruch oder Aufbruch? Eine Nachlese, Stimmen der Zeit (2016/11) 723-732.

71 Tomás de Aquino, S. Th., I-II, q. 9, a. 4 in c. 
Es interesante notar que Tomás de Aquino no está diciendo que el conocimiento de la realidad de cada uno, la situación de cada hombre, encierre una verdad más significativa que la norma general, que siempre puede fallar propter generalitatem. Lo que está diciendo es que para juzgar con verdad acerca de un caso particular es necesario tener la ciencia más adecuada, más cercana al caso que se juzga. En otras palabras, la norma general que más adecuadamente describa y formule el caso concreto, la que más se acerque a él ${ }^{72}$. Los juristas solemos enunciar esta misma idea con la conocida regla de que el género se deroga por la especie, o que la norma específica prevalece sobre la genérica. Si yo sé, por ejemplo, que el matrimonio es indisoluble, pero ignoro que el matrimonio rato y no consumado puede ser disuelto por una concesión pontificia, me faltará una ciencia específica que me ayudaría mucho a resolver mejor el problema de Ticio y Caya, que no han consumado su matrimonio. Santo Tomás está hablando de ciencia, no del discernimiento de casos. Por seguir con los ejemplos tomasianos: conocer que la carne de las aves es más suave que la carne de otros animales es un grado de ciencia (de conocimiento general) ${ }^{73}$; conocer que los depósitos han de ser devueltos con tales cauciones o siguiendo tales formalidades es también un grado de ciencia ${ }^{74}$, que santo Tomás llama particular, derivada o conclusiva, porque resulta una conclusión de principios más altos. Por otra parte, Tomás de Aquino tampoco afirma que la indeterminación propia de las conclusiones derivadas que exige el conocimiento de lo particular sea de suyo una relevante mejora para el conocimiento. Es sin duda una necesidad para la elección verdadera y justa de la prudencia. Pero es también una ocasión de error y de vicio. En algunos preceptos particulares y derivados puede originarse un mayor grado de desconocimiento y de error, «debido a que algunos tienen la razón oscurecida por una pasión, por una mala costumbre o por una torcida disposición natural. Y así cuenta Julio César [...] que entre los germanos no se consideraba ilícito el robo a pesar de que es expresamente contrario a la ley natural» ${ }^{75}$.

\footnotetext{
72 Cfr. N. MARTíNeZ, Otra referencia a Santo Tomás en «Amoris Laetitia», infocatolica.com, 17-IV2016 [goo.gl/NdMuC1].

73 Cfr. TOMÁs de AQuino, Sententia libri Ethicorum, VI, 6).

${ }^{74}$ Cfr. Tomás de Aquino, S. Th., I-II, q. 9, a. 4 in c.

75 Tomás de Aquino, S. Th., I-II, q. 94, a. 4 in c.
} 


\subsection{La fragilidad}

Todo el capítulo octavo de Amoris Laetitia gira en torno a la fragilidad. Es uno de sus objetivos, como expresa su propio título. Una fragilidad que hay que acompañar, discernir e integrar. La Iglesia «es consciente de la fragilidad de muchos de sus hijos» (AL, 291). En realidad sería inoportuno que cualquiera se sintiera fuerte, y por lo tanto habrá que decir que todos los hijos de la Iglesia son frágiles. Pero la verdadera atención va dirigida a «acompañar con atención y cuidado a sus hijos más frágiles» (AL, 291), es decir, no simplemente los que tienen riesgo de fractura, sino a los que se han roto ya. A los que están «marcados por el amor herido y extraviado» (AL, 291). Amoris Laetitia no tiene ninguna duda, porque no cabe tenerla, acerca de que «Jesucristo quiere una Iglesia atenta al bien que el Espíritu derrama en medio de la fragilidad» (AL, 308). Y por lo tanto, «los pastores, que proponen a los fieles el ideal pleno del Evangelio y la doctrina de la Iglesia, deben ayudarles también a asumir la lógica de la compasión con los frágiles» (AL, 308). Ante ellos, «el camino de la Iglesia, desde el concilio de Jerusalén en adelante, es siempre el camino de Jesús, el de la misericordia y de la integración» (AL, 296), es decir, «atentos al modo en que las personas viven y sufren a causa de su condición» (AL, 296), de su frágil condición.

Ahora bien, hay muchos modos de ser frágiles. «El Sínodo se ha referido a distintas situaciones de fragilidad o imperfección» (AL, 296). Y no es sencillo entender a fondo la extensión de la fragilidad. Hay que saber exactamente qué es lo que se puede romper y cómo. Puede ser frágil una unión, un matrimonio. En ese caso la especial atención a la fragilidad sería la atención a los matrimonios rotos. Puede ser frágil el alma de las personas, que rompe su comunión con Dios. Puede ser frágil la relación del pecador con la Iglesia, y entonces pensamos en la integración en la vida eclesial. Puede ser frágil la misma interioridad de cada uno, que a veces se rompe y produce dolor, y requiere compasión y compañía. Por último tenemos la fragilidad como riesgo, como virtualidad. Un jarrón frágil es un jarrón que no se ha roto por ahora. Y en este sentido tenemos que doblar la tipología de la fragilidad. Una unión frágil es una unión que no se ha roto pero que se puede romper. Un alma frágil es un alma que no ha roto su comunión con el Señor, pero que la puede romper. Y así en los demás casos. Como se ve, la fragilidad, como la misericordia, tiene una fenomenología extremadamente amplia.

Amoris Laetitia entiende por frágiles sobre todo a las personas que sufren por el amor herido y a los fieles que han roto la comunión con la Iglesia y no 
se sienten integrados. Ésos serían los modelos típicos de la fragilidad de la exhortación apostólica. También hay alusiones al resto de las fragilidades de hecho. Hay pocas alusiones en el capítulo octavo a la fragilidad virtual, aunque obviamente no se niega. Pienso que si entendemos la fragilidad en sentido amplio promoveríamos también una lectura amplia de Amoris Laetitia. Existen al menos tres aprovechamientos interesantes sobre esta amplitud de la fragilidad.

El primero es que hay que atender también a la fragilidad virtual de las personas y de las instituciones. El matrimonio es de vidrio, cada matrimonio y el matrimonio como institución. Necesita mucha atención misericordiosa. Ya hemos dicho que el sujeto de la misericordia es considerablemente más amplio de lo que uno piensa. Un frágil de hecho (alguien que ha roto su relación, o se ha roto él mismo) debe ser siempre el objetivo inmediato de la misericordia. Pero nunca es un objetivo absoluto, porque hay modos de tratar a los frágiles que condicionan la fragilidad virtual de los demás y la propia institución matrimonial. Una fragilidad de hecho convertida en normalidad de derecho se haría a su vez estímulo de la ruptura.

La segunda indicación tiene que ver con el modo de entender algunas expresiones. Integrar la fragilidad, que es una expresión característica de Amoris Laetitia, se entiende en la exhortación apostólica como la acción y el efecto de acoger en el seno de la Iglesia, a través de funciones comunitarias y actitudes personales, a los que se encuentran en las situaciones llamadas «irregulares» ${ }^{76}$. Es un modo indudable de integrar la fragilidad. Sin embargo, querría indicar algo muy sencillo: «integrar la fragilidad», según el significado más inmediato de los términos, quiere decir unir lo que se rompió. Volver a incorporar en la unidad de un cuerpo íntegro a los esposos, recuperar la unidad que se había perdido. Hay que reconocer que se trata de un asunto muy difícil, pero constituye, no sólo desde el punto de vista semántico y lingüístico, sino también teológico, la primera connotación de esta fórmula. Integrar la fragilidad no quiere decir que cada una de las partes rotas rehaga su vida, eso sería desintegrar la fragilidad.

Un tercer aspecto paradójico de la fragilidad tendría que ver con el sentimiento herido. Una de las expresiones frecuentes dentro de nuestro lenguaje eclesiástico es que hay que hacerse cargo de la cantidad de matrimonios rotos que sufren en nuestro mundo. No hay ninguna duda de que ese sufri-

${ }^{76}$ Cfr. A. VIANA, ¿Son idóneos para el oficio eclesiástico los divorciados que contraen nuevo matrimonio civil?, Ius Canonicum 112 (2016) 515-553. 
miento existe, cualquiera puede ser testigo de él. Pero en realidad cuando hablamos del sufrimiento de la ruptura ordinariamente nos referimos a nuevas parejas «consolidadas en el tiempo». Ahora sufren no tanto porque sean frágiles, sino porque no pueden ser tan estables como querrían. Lo que les produce incomodidad no es la vida matrimonial frágil sino un reconocimiento insuficiente de su unión por parte de la Iglesia.

\subsection{El ideal del matrimonio}

Entre las diversas «situaciones de fragilidad o imperfección» se encuentran sobre todo los divorciados que han emprendido una nueva unión «consolidada en el tiempo, con nuevos hijos, con probada fidelidad, entrega generosa, compromiso cristiano, conocimiento de la irregularidad de su situación y gran dificultad para volver atrás sin sentir en conciencia que se cae en nuevas culpas» (AL, 298). Esta situación es «imperfecta» si se mira al «ideal pleno del matrimonio» (AL, 307), pero el discernimiento «debe ayudar a encontrar los posibles caminos de respuesta a Dios y de crecimiento en medio de los límites. Por creer que todo es blanco o negro a veces cerramos el camino de la gracia y del crecimiento, y desalentamos caminos de santificación que dan gloria a Dios» (AL, 305).

Una de las constantes del capítulo octavo de Amoris Laetitia sería el crecimiento posible en medio de los límites. «Creo sinceramente que Jesucristo quiere una Iglesia atenta al bien que el Espíritu derrama en medio de la fragilidad: una Madre que, al mismo tiempo que expresa claramente su enseñanza objetiva, "no renuncia al bien posible, aunque corra el riesgo de mancharse con el barro del camino" [Evangelii Gaudium, 45]» (AL, 308). Para ello se establece el ideal, que es el matrimonio natural y revelado, con sus fines y sus propiedades, y a continuación los modos de participar en él. «Otras formas de unión contradicen radicalmente este ideal, pero algunas lo realizan al menos de modo parcial y análogo» (AL, 292). «Los Padres sinodales expresaron [Relatio Synodi, 2014,41.43; 2015,70] que la Iglesia no deja de valorar los elementos constructivos en aquellas situaciones que todavía no corresponden o ya no corresponden a su enseñanza sobre el matrimonio» (AL, 292). «Es preciso afrontar todas estas situaciones de manera constructiva, tratando de transformarlas en oportunidad de camino hacia la plenitud del matrimonio y de la familia a la luz del Evangelio. Se trata de acogerlas y acompañarlas con paciencia y delicadeza» (AL, 294). El proyecto de Amoris 
Laetitia consiste en acoger las uniones more uxorio no matrimoniales en la medida que reproducen analógicamente o participan parcialmente de la realidad matrimonial. Descubrir el bien posible y dedicarle la atención posible. Este rasgo de ejercicio de la misericordia suscita algunas preguntas para su interpretación in altum.

\subsubsection{Matrimonio y vida matrimonial}

El matrimonio puede ser concebido como ideal de muchos modos. Por ejemplo, en su significado de unión de Cristo con la Iglesia. Es indudable que los esposos nunca llegarán a agotar este modelo. También se puede hablar de ideal en la vida de un matrimonio. Un matrimonio siempre podrá demostrar mejor el amor. La vida matrimonial es una constante demanda de generosidad, de comprensión y de afecto. Y siempre adolecerá de algo, sin agotar el ideal del amor ${ }^{77}$.

¿Quiere esto decir que algunas formas de unión realizan de modo parcial y análogo el ideal del matrimonio? La vida more uxorio no matrimonial (uniones de hecho, divorciados casados de nuevo) tiene múltiples analogías con la vida matrimonial. Lo que no existe es identidad ni analogía en el ser. Las uniones uxorias no matrimoniales y el matrimonio no son idénticos, ni siquiera análogos ${ }^{78}$. Es más, frecuentemente se ponen como ejemplos de contraste. Para calibrar lo que es el matrimonio no se pone como ejemplo de disparidad una sociedad anónima o un contrato de seguros sino una unión more uxorio no matrimonial. Entonces se entiende exactamente que esa unión, aunque pueda tener numerosas semejanzas de hecho, no tiene precisamente los elementos, los fines y las propiedades del matrimonio, sino que es su opuesto. Por eso, decir que realiza parcial y analógicamente el ideal del matrimonio se debe entender en un sentido menor y derivado. Puede asemejarse a algunas actitudes propias de la vida matrimonial. Pueden vivir igual, hacer lo mismo. Pero en esto los hechos puros son poco de fiar.

${ }^{77}$ Es evidente el riesgo que se deriva de atribuir por una parte al matrimonio la carga de ideal con todas sus exigencias (de modo que se pueda reconocer la invalidez de las uniones que no cumplan perfectamente el modelo), y de sustraer por otra parte su carga de ideal para reconocer como matrimoniales situaciones análogas al matrimonio. Esta doble voluntad contradictoria puede hacerse presente de modo inconsciente en la vida pastoral.

${ }^{78}$ No incluyo en esta afirmación el caso de los católicos que han contraído matrimonio civil sin establecer una segunda unión more uxorio. 


\subsubsection{La extensión analógica}

Para entender todo esto ayuda bastante la llamada extensión analógica. En la interpretación y en la suplencia de ley positiva se emplea mucho la analogia legis y la analogia iuris. Desde siempre, la doctrina y la jurisprudencia ha procurado poner condiciones para que un exceso analógico no defraude el orden jurídico. De ahí nació la exigencia de que la aplicación analógica, además de la semejanza de caso presentara también paridad de razón. Lo cual no resuelve todos los problemas, porque «no falta nunca una cualidad, cualquiera que sea, capaz de establecer semejanza entre dos casos. Si no es la forma puede ser el color, o el tamaño, o la textura. La semejanza no es un absoluto, sólo la identidad lo es. Dos cosas semejantes en un punto pueden ser contradictorios en otro» ${ }^{79}$. Las analogías se pueden forzar muy fácilmente. Es más, si uno busca analogías puede encontrarlas siempre, porque hay muchas. Unas son pertinentes, otras menos, algunas no lo son en absoluto.

Ahora bien, el hecho de que una analogía no sea pertinente no quiere decir que no sea argumentable. Ni siquiera significa que no sea persuasiva. La argumentación y la persuasión dependen a veces más de la retórica que de la verdad. Pongamos por ejemplo la unión polígama. Es una prueba que se puede hacer sin ningún riesgo, porque el supuesto goza del mayor descrédito cultural y social. Es innegable que en una unión polígama puede existir, y existe con frecuencia entre sus miembros, un afecto verdadero. Muchas mujeres aceptan con plena libertad su condición de esposa en común con otras. Mujeres que aman a su esposo, un esposo que ama a sus mujeres, madres que engendran hijos a los que aman y de los que cuidan, con las limitaciones obvias del amor encarnado. ¿Qué es lo que lleva a no considerar eso un matrimonio? ¿Por qué Betsabé sí y Abigaíl no, si las dos me las ha concedido el Señor, podría preguntar David? ¿No deberíamos pensar que, así como se acepta con una absoluta naturalidad la poligamia diacrónica, una mujer detrás de otra después del divorcio, se podría aceptar también la poligamia sincrónica, todas las esposas a la vez, siempre que ellas lo acepten? ¿Quién va a negar la acogida de la segunda o tercera mujer que viene a la comunión familiar con amor verdadero? ¿Es que no está ahí la gracia de Cristo y la misericordia del Señor?

79 J. Otaduy, «Analogía en el derecho», en J. Otaduy - A. Viana - J. Sedano, Diccionario General de Derecho Canónico, I, Universidad de Navarra/Thompson Reuters-Aranzadi, Pamplona 2012, 324. 
Esto es una gran mentira, por supuesto, pero una mentira asentada en múltiples analogías que tienen fundamento innegable en los hechos de la vida uxoria. Lo mismo, más fácilmente aún, se podrían encontrar aspectos de analogía con el matrimonio en una unión estable de hecho en la que no se desea compromiso matrimonial alguno.

Dicho sea de paso, cuanto menos razonabilidad objetiva tiene un argumento, cuanto más amplias y menos densas son las analogías, menos tropiezan con pruebas que las desacrediten de modo directo. Digamos que cuando más analógico es un razonamiento menos impactos puede recibir. Es como disparar a una nube de colores. A los argumentos vacíos es muy difícil oponerse, de modo que pueden salir indemnes de casi todas las batallas sin haber entrado en ellas.

\subsection{El alimento eucarístico}

Hay dos referencias en Amoris Laetitia que han concitado la atención universal. Son dos notas a pie de página acerca de la hipotética y condicionada participación en los sacramentos de los fieles en situación irregular. En la primera de ellas se dice que «las consecuencias o efectos de una norma no necesariamente deben ser siempre las mismas», y se remite a pie de página para completar la frase diciendo que «tampoco en lo referente a la disciplina sacramental, puesto que el discernimiento puede reconocer que en una situación particular no hay culpa grave» (AL, 300, nt 336). A su vez, la cita dirige explícitamente a los números 44 y 47 de la Exhortación apostólica Evangelii Gaudium. «La Eucaristía, si bien constituye la plenitud de la vida sacramental, no es un premio para los perfectos sino un generoso remedio y un alimento para los débiles» (EG, 47). Aquí se hace referencia a dos textos de san Ambrosio y a uno de san Cirilo de Alejandría. «Tengo que recibirle siempre, para que siempre perdone mis pecados. Si peco continuamente, he de tener siempre un remedio» ${ }^{80} ;$ «El que comió el maná murió; el que coma de este cuerpo obtendrá el perdón de sus pecados» ${ }^{81}$. $\ll$ Me he examinado y me he reconocido indigno. A los que así hablan les digo: ¿YY cuándo seréis dignos? ¿Cuándo os presentaréis entonces ante Cristo? Y si vuestros pecados os impiden acercaros y si nunca vais a dejar de caer -¿quién conoce sus delitos?, dice el salmo-, ¿̇os que-

\footnotetext{
${ }^{80}$ SAN Ambrosio, De Sacramentis, IV, 6, 28: PL 16, 446.

${ }^{81}$ Ibid., IV, 5, 24: PL 16, 463.
} 
daréis sin participar de la santificación que vivifica para la eternidad?» ${ }^{82}$. Evangelii Gaudium, 47 acaba con estas palabras: «Estas convicciones también tienen consecuencias pastorales que estamos llamados a considerar con prudencia y audacia. A menudo nos comportamos como controladores de la gracia y no como facilitadores. Pero la Iglesia no es una aduana, es la casa paterna donde hay lugar para cada uno con su vida a cuestas».

El otro texto de Amoris Laetitia sobre nuestro tema dice así: «A causa de los condicionamientos o factores atenuantes, es posible que, en medio de una situación objetiva de pecado -que no sea subjetivamente culpable o que no lo sea de modo pleno- se pueda vivir en gracia de Dios, se pueda amar, y también se pueda crecer en la vida de la gracia y la caridad, recibiendo para ello la ayuda de la Iglesia». En nota se comenta: «En ciertos casos, podría ser también la ayuda de los sacramentos» (AL, 305, nt 351).

\subsubsection{Sacramenta propter homines}

De la lectura de la exhortación apostólica y de los textos recién citados de san Ambrosio y san Cirilo de Alejandría (y otros muchos a los que se podría remitir) resulta que la Eucaristía es un alimento necesario para la salvación, que no es un premio para los perfectos sino un alimento para los débiles, que una de sus funciones naturales es purificar el alma del pecado. Sacramenta propter homines. El Señor no ha instituido estos signos e instrumentos de salvación para que sean admirados sino para que sean empleados. Nunca estaremos a la altura de semejante don. Estas verdades forman parte de la doctrina católica sobre la Eucaristía.

La Eucaristía es un alimento para los débiles, y siempre lo será. Propter bomines quiere decir en definitiva que los sacramentos están al servicio de la salvación y no la salvación al servicio de los sacramentos. El signo sacramental es la humildad de Dios salvador que se pone al servicio de la debilidad humana, sin miedo al «riesgo de mancharse con el barro del camino» (AL, 308; Evangelii Gaudium, 45). Un sacramento soporta siempre el contacto con la condición humana, es decir, el encuentro con un amor débil, distraído, menor, incluso condicionado. Los sacramentos están para ser recibidos, no para ser admirados. Aunque también hay que decir, desde luego, que quien no los admira tiene pocas posibilidades de recibirlos bien.

82 San Cirilo de Alejandría, In foh. Evang. IV, 2: PG 73, 584-585. 


\subsubsection{La Eucaristía y el pecado}

La condición de necesidad del alimento eucarístico es innegable porque el Señor lo ha dicho expresamente. Si no comemos su carne y no bebemos su sangre no tenemos vida. Ahora bien, frecuentemente el alimento eucarístico requiere una purga del corazón y de las obras. Tenemos textos de la Sagrada Escritura que no dejan lugar a dudas sobre el particular. «No podéis participar de la mesa del Señor y de la mesa de los demonios, ¿o es que queremos provocar la ira del Señor?» (1 Cor 10,21-22). Y sobre todo la conocidísima advertencia del apóstol un capítulo más adelante de la misma epístola a los corintios: «quien coma el pan o beba el cáliz del Señor indignamente, será reo del cuerpo y de la sangre del Señor. Examínese, por tanto, cada uno a sí mismo, y entonces coma del pan y beba del cáliz; porque el que come y bebe sin discernir el Cuerpo, come y bebe su propia condenación» (1 Cor 11,27-29).

Una disposición débil es muy distinta de una disposición indigna. El que ofende y se arrepiente es débil, el que ofende y no se arrepiente es injurioso. Los sacramentos son para los hombres, pero para los hombres que quieren recibir la salvación. Cuando se lee lo referente a la función curativa de la Eucaristía es muy interesante distinguir entre la comunión eucarística en el contexto de la debilidad cotidiana y en el contexto del pecado sin conversión ${ }^{83}$. En este punto también cabe una interpretación in altum de los textos de san Ambrosio y san Cirilo de Alejandría citados en Amoris Laetitia.

Veamos primero el texto de san Ambrosio. «Tengo que recibirle siempre, para que siempre perdone mis pecados. Si peco continuamente, he de tener siempre un remedio» ${ }^{84}$. Ambrosio se dirige a los neófitos, recién salidos de las aguas bautismales. Tiene la intención de introducir a los recién bautizados en la importancia de la comunión frecuente. No está de acuerdo en absoluto con la praxis de algunas iglesias de Oriente: «si el pan es cotidiano, ¿por qué lo vas a tomar una vez al año, como acostumbraban a hacer algunos griegos en Oriente? Tómalo cada día, que cada día te aprovecha» ${ }^{85}$. La fuerza de su argumento es ésa, teniendo presente que se está dirigiendo a cristianos bien dispuestos y recién bautizados. El pecado de cada día, el pecado continuo, es el

${ }^{83}$ Sobre la recepción de la comunión eucarística para la remisión de los pecados, cfr. A. GARCía IbáÑEZ, La Eucaristía, don y misterio. Tratado bistórico-teológico sobre el misterio eucarístico, Eunsa, Pamplona 2009, 575-583.

${ }^{84}$ San Ambrosio, De Sacramentis, IV, 5, 24: PL 16, 463.

${ }^{85}$ Ibid., V, 4, 25: PL 16, 379. 
pecado venial. Santo Tomás, hablando de los efectos del sacramento de la Eucaristía dice precisamente que «corresponde a este sacramento perdonar los pecados veniales. De ahí que san Ambrosio diga en su libro De sacramentis que este pan cotidiano se toma para remedio de nuestra cotidiana debilidad $\gg^{86}$. San Ambrosio habla específicamente de la debilidad cotidiana: «tómalo cada día para que cada día pidas perdón por tu deuda ${ }^{87}$. Pero no tenía además ninguna duda de que era necesario estar bien dispuesto para recibir la Eucaristía. Recordemos su estímulo para recibir cotidianamente la Eucaristía. Dice a continuación: «vive de tal modo que merezcas recibirlo cada día. El que no merece recibirlo cada día, tampoco merece recibirlo al cabo de un año» ${ }^{88}$.

También el texto de san Cirilo de Alejandría leído antes merece una interpretación integral. Sus palabras son igualmente un estímulo fortísimo a la recepción de la Eucaristía y a la confianza en la gracia para el perdón de los pecados: «Me he examinado y me he reconocido indigno. A los que así hablan les digo: ¿Y cuándo seréis dignos? ¿Cuándo os presentaréis entonces ante Cristo? Y si vuestros pecados os impiden acercaros y si nunca vais a dejar de caer - ¿quién conoce sus delitos?, dice el salmo-, ¿os quedaréis sin participar de la santificación que vivifica para la eternidad?». Parece necesario sin embargo leer las palabras que vienen inmediatamente a continuación: «por tanto, decídete a vivir recta y honestamente, y participa de la Eucaristía» ${ }^{89}$. Es claro que san Cirilo no pensaba en una recepción inadecuada de la Eucaristía, sin suficiente conversión de los pecadores.

\subsubsection{El derecho a la administración de los sacramentos}

Los canonistas hemos recordado sin cesar, porque está en los fundamentos del ordenamiento canónico, la formulación del actual c. 213: «Todos los fieles tienen derecho a recibir de los pastores sagrados la ayuda de los bienes espirituales de la Iglesia, principalmente la Palabra de Dios y los sacramen-

${ }^{86}$ Santo Tomás de Aquino, S. Th., III, q. 79, a. 4 in c. En realidad toda la q. 79, referida a los efectos de la Eucaristía, es de gran interés para este tema, sobre todo los aa. 3-6, en los que se refiere a los pecados presentes, pasados y futuros. Según santo Tomás, este sacramento no puede producir la remisión del pecado en quien lo recibe con conciencia de pecado mortal.

87 San Ambrosio, De sacramentis, VI, 4, 24: PL 16, 385.

${ }^{88}$ Ibid., V, 4, 25: PL 16, 379.

89 San Cirilo de Alejandría, In foh. Ev. 6,57, Lib. IV, cap. 2, en L. LeOne (trad., intr. e note), S. Cirillo di Alessandria, Commento al Vangelo di Giovanni 1 (Libri I-IV), Città Nuova, Roma 1994, 508 [traducción propia]. 
tos». Siempre que se menciona este canon se suele hacer una distinción que ya es típica. El derecho a la administración de los sacramentos no es un derecho sobre los sacramentos. La relación jurídica no se establece entre el sacramento y el fiel, sino entre el que administra y el que recibe. Es un derecho que liga al fiel con los pastores para que le sea dispensado razonable y justamente el don. Junto a esta distinción elemental, necesaria para no establecer incongruencias como un derecho a la gracia o un dominio sobre el cuerpo y la sangre del Señor, se añade también que es un derecho con sus propios límites, como todos los derechos. Algunos tienen menos límites, como los puros derechos de libertad, en los que se pide a todos que respeten las decisiones ajenas. Pero éste no es un simple derecho de libertad. Para que a un fiel se le administren los sacramentos se exige obviamente que sea capaz de recibirlos, que lo pida razonablemente y que cumpla las condiciones que la Iglesia establece. Y lógicamente que esté bien dispuesto, «se examine a sí mismo» y «discierna el cuerpo» (1 Cor 11,28.29).

La Eucaristía se debe entender en un clima de gracia y de misericordia. De lo contrario no se entendería nada. Aquí comparecen requisitos originarios del Evangelio y la argumentación debe ser muy delicada. La Eucaristía es un alimento necesario. Todo fiel tiene derecho a que le sean administrados la palabra y los sacramentos. Los sacramentos son para ellos, propter homines. Son una ayuda para la debilidad. Si menoscabamos cualquiera de estas exigencias tiramos por tierra la teología sacramentaria. Sin embargo es un gran riesgo y un error maligno entender lo gratuito como un derecho y la Eucaristía como un alimento de mi propia despensa.

La Iglesia no administra la Eucaristía con criterios de justicia social (pan para todos), ni con criterios de justicia conmutativa (pan para el que lo pague), ni con criterios de justicia distributiva (pan para quien lo merezca), ni con criterios de justicia legal (pan para quien se establezca), sino con criterios de dispensación. Dispensa un pan que no es suyo, o al menos un pan que es tan suyo como la gracia. Es suyo porque vive de él, porque ha recibido el poder de confeccionarlo y de administrarlo. Pero es un pan dado en préstamo y en prenda. Es un préstamo para el camino, y una prenda del destino final. Y el título en virtud del cual la Iglesia lo posee es la pasión de su Señor, no un contrato de libre disposición. Por eso la Iglesia no sólo debe dar de comer, sino que, como buena madre, debe enseñar a comer. 


\section{Bibliografía}

Álvarez de las Asturias, N. (ed.), En la salud y en la enfermedad. Pastoral y derecho al servicio del matrimonio, Cristiandad, Madrid 2015.

Ambrosio de Milán, Des sacrements. Des mystères. Explication du symbole, Editions du Cerf, Paris 1961.

-, Opere esegetiche VIII/1, Commento al Salmo CXVIII (Lettere I-XI), (introd., trad., note e indici a cura di L. F. Pizzolato), Biblioteca Ambrosiana, Milano 1987 - Città Nuova Editrice, Roma 1987.

Antonelli, E., Tra regole ed eccezioni, un difficile equilibrio, Settimo Cielo di Sandro Magister, 6-VII-2016 [goo.gl/nZ01eW].

—, «Amoris Laetitia»: Para su interpretación y aplicación, www.familiam.org, octubre 2016 [goo.gl/kcZBkx].

ANTUla, J., La verdadera novedad de «Amoris Laetitia», Religión Digital, 21IV-2016 [goo.gl/lGeqKW].

Bagnasco, A., Presentazione alla Diocesi di Genova dell'Esortazione Apostolica «Amoris Laetitia», Avvenire, 15-IV-2016 [goo.gl/xV8Lch].

BALDISSERI, L., Intervento nella conferenza stampa per la presentazione dell'Esortazione Apostolica post-sinodale del Santo Padre Francesco «Amoris Laetitia», sull'amore nella famiglia, 8-IV-2016 [goo.gl/kkt73n].

BARTHE, C., L'instinct de la foi, hommenouveau.fr, 8-IV-2016 [goo.gl/wBdM3p]. —, Entrevista de Roberto de Mattei, adelantelafe.com, 9-V-2016 [goo.gl/7zp5a9].

Baura, E., Primacía de la persona. Misericordia, oikonomia y derecho, en N. Álvarez DE LAS Asturias (ed.), En la salud y en la enfermedad. Pastoral y derecho al servicio del matrimonio, Cristiandad, Madrid 2015, 75-111.

Bellon, A., Istruzioni per la lettura dell'esortazione postsinodale «Amoris letitia», Settimo Cielo di Sandro Magister, 5-V-2016 [goo.gl/bh3cKd].

BlázQuez PÉReZ, R., Nell'Amoris Laetitia. Il magistero della gioia, L'Osservatore Romano, 15-IV-2016.

Bogarín DíAz, J., Repercusiones canónicas de «Amoris Laetitia», Revista General de Derecho Canónico y Derecho Eclesiástico del Estado 41 (2016) (RI $\$ 417440)$.

BRANDMÜller, W., Entrevista en katholisch.de (traducción de B. Moreno), InfoCatólica, 6-V-2016 [goo.gl/tBFk2o].

Brandmüller, Card. W. - Burke, Card. R. L. - Caffarra, Card. C. MeISner, Card. J., Fare chiarezza. Nodi irrisolti di «Amoris Laetitia». Un appello, chiesa.espresso.repubblica.it, 14-XI-2016 [goo.gl/cSq1gF]. 
BRUgGer, E. C., Five serious problems with Chapter 8 of «Amoris Laetitia», Catholic World Report, 22-IV-2016 [goo.gl/iUj0Qh].

Burke, R., «Amoris Laetitia» and the Constant Teaching and Practice of the Cburch, National Catholic Register, 12-IV-2016 [goo.gl/aK0MXH].

Buttiglione, R., La gioia dell'amore e lo sconcerto dei teologi. A proposito di alcuni commenti sull'esortazione apostolica di papa Francesco «Amoris laetitia», L'Osservatore Romano, 20-VII-2016.

CAFFARRA, C., «Amoris Laetitia». Il coraggio del cammino, Tracce.it, 12-IV-2016 [goo.gl/axQvWI].

—, Intervista di Marco Ferrarese, La nuova Bussola Quotidiana, 25-V-2016 [goo.gl/6aCq5b].

—, Interview by Maike Hickson, OnePeterFive, 11-VII-2016 [goo.gl/ct4CBC].

CASANOVA, C. A., Una risposta all'interpretazione di «Amoris Laetitia» fatta di Rocco Buttiglione, Settimo Cielo di Sandro Magister, 20-X-2016 [goo.gl/uVf1Z].

Chaput, Ch. J., Pastoral Guidelines for Implementating «Amoris Laetitia», Archdiocese of Philadelphia, archphila.org, 1-VII-2016 [goo.gl/iClYXc].

De PaOlIs, V., I divorziati risposati e i sacramenti dell'Eucarestia e della Peniten$z a$, Inaugurazione del nuovo anno giudiziario del tribunale ecclesiastico regionale dell'Umbria, 27-III-2014 [goo.gl/kaqC6u].

ERRÁZuRIz MaCKenNa, C. J., Matrimonio y justicia objetiva en la comunión eclesial: un aspecto del discernimiento pastoral propiciado por «Amoris laetitia», Collationes, 25-V-2016 [goo.gl/fXfjgL].

Fedele, P., Aequitas canonica, Apollinaris 51 (1978) 415-439.

Fernández, V. M., La dimensión trinitaria de la moral. II. Profundización del aspecto ético a la luz de «Deus caritas est», Revista Teología 89 (2006) 133-163.

Formicola, G., Lettera, Settimo Cielo di Sandro Magister, 27-IX-2016 [goo.gl/ Ffu93L].

Fumagalli, A., La «via caritatis». Sul capitolo ottavo di «Amoris Laetitia», La Rivista del Clero Italiano 2016/7-8 (citado por Settimo Cielo di Sandro Magister, 9-VIII-2016 [goo.gl/uVf1Z]).

GAHL, R. A. JR., Guarire attraverso il pentimento. Una risposta alla lettura di Rocco Buttiglione della «Amoris laetitia», Settimo Cielo di Sandro Magister, 2VIII-2016 [goo.gl/qxsLJN].

García IbáÑEZ, A., La Eucaristía, don y misterio. Tratado histórico-teológico sobre el misterio eucarístico, Eunsa, Pamplona 2009.

Gargano, G. I., Una lettura di «Amoris Laetitia», camaldolesiromani.com [goo.gl/J8a6xf]. 
Gracián, A., Inconveniencias eclesiales, IV, V-VIII, InfoCatólica, 25-IV2016/30-V-2016 [goo.gl/gLdGFf], [goo.gl/NgB4lB], [goo.gl/LxoR0C], [goo.gl/kDAHBI].

GRANADOS, J., Intervista di Riccardo Cascioli, La nuova Bussola Quotidiana, 9IV-2016 [goo.gl/oxQXM3].

Grichting, M., Un adiós al matrimonio cristiano, CatolicosOn-line.org [goo.gl/PvLl7z].

GRILlo, A., Alla scoperta di «Amoris Laetitia» (1-19), Munera, Rivista europea di cultura, cittadellaeditrice.com, 10-IV-2016/16-VII-2016 [goo.gl/ZT2Sg7].

Gronchi, M., Dottrina e fede cristiana. L'esortazione «Amoris Laetitia» tra Newman e Paolo VI, L'Osservatore Romano, 14-IV-2016.

GuERra LÓPEz, R., Entrevista de faime Septién, Aleteia, 3-V-2016 [goo.gl/ $4 \mathrm{uSf} 0 \mathrm{~S}]$.

—, Fedeltà creativa. Dalla riflessione di Karol Wojtyla all'esortazione «Amoris laetitia», L'Osservatore Romano, 23-VII-2016 [goo.gl/ORY9XS].

Iraburu, J. M., Amoris laetitia (1-9), InfoCatolica, 8-IV-2016/24-VI-2016 [goo.gl/NmP0tG], [goo.gl/6fQIEP], [goo.gl/w1gT4f], [goo.gl/zGy6wy], [goo.gl/DePGcv], [goo.gl/oSkt71], [goo.gl/lncxyv], [goo.gl/TBv2EW], [goo.gl/pzHqu3].

KASPER, W., La misericordia. Clave del Evangelio y de la vida cristiana, Sal Terrae, Santander 2013.

—, Entrevista, Aachener Zeitung/InfoCatólica, 22-IV-2016 [goo.gl/SWYxKI].

—, «Amoris laetitia»: Bruch oder Aufbruch? Eine Nachlese, Stimmen der Zeit (2016/11) 723-732.

KathPress [Katholische Presseagentur], «Amoris laetitia». Theologen sehen Ortskirchen am Zug, Kath.net, 12-VI-2016 [goo.gl/eqLDul].

LEFEBVRE, Ch., La doctrine de l'Hostiensis sur la préférence à assurer en droit aux intérêts spirituels, Ephemerides iuris canonici 8 (1952) 22-44.

—, «Aequitas canonica» et «periculum animae» dans la doctrine de l'Hostiensis, Ephemerides iuris canonici 8 (1952) 305-321.

Liv, A., Dottrina morale e prassi pastorale nella «Amoris laetitia», Unione Apostolica Fides et Ratio, 10-V-2016 [goo.gl/GvleC6].

-, Tante affermazioni che vanno chiarite, La nuova Bussola Quotidiana, 13-IV2016 [goo.gl/4pNij2].

Marafioti, D., Una lettura dell'Essortazione «Amoris Laetitia», Ascolta 195 (2016) 2-3 [goo.gl/pO9CsP]. 
Marcotullio, G., «Amoris latitia» tra Fellay e Melloni: letture ed errori, La Crocequotidiano.it, 16-IV-2016 [goo.gl/mvSbn8].

Martínez, N., Algunas observaciones sobre la imputabilidad en «Amoris Laetitia», 9-IV-2016 [goo.gl/lhrI77].

—, Otra referencia a Santo Tomás en «Amoris Laetitia», infocatolica.com, 17-IV2016 [goo.gl/NdMuC1].

MeLinA, L., Nota, Il Foglio, 11-IV-2016 [goo.gl/qlcPkV].

MeLloni, A., Francesco e la riforma dell'amore, La Repubblica.it, 9-IV-2016 [goo.gl/2tKio7].

Merecki, J., Fedeltà troppo creativa diventa infedeltà, Settimo Cielo di Sandro Magister, 4-VIII-2016 [goo.gl/tzZ87J].

Mock, B., Nell'esortazione apostolica «Amoris Laetitiia». Partecipazione invece di condanna, L’Osservatore Romano, 4-V-2016.

Morselli, A., Osservazioni su alcuni punti controversi dell'Esortazione apostolica «Amoris laetitia», Messainlatino.it, 29-V-2016 [goo.gl/ZO5uek].

MüLLER, G. L., ¿Qué podemos esperar de la familia?, 4-V-2016 [goo.gl/D5Vqad].

Obispos de la Región de Buenos Aires, Intercambio de cartas con el papa Francisco sobre los «Criterios básicos para la aplicación del capitulo 8 de Amoris Laetitia», Il Sismografo, 11-IX-2016 [goo.gl/i0eaNQ].

OliveIRA, J. E. DE, Chaves de leitura para «Amoris latitia», Collationes [goo.gl/ yXxdVI].

Ortiz, M. A., También llamados a la santidad. La pastoral de los fieles divorciados y vueltos a casar civilmente, en N. ÁLVAREZ DE LAS ASTURIAS (ed.), En la salud y en la enfermedad. Pastoral y derecho al servicio del matrimonio, Cristiandad, Madrid 2015, 113-157.

Paprocky, T. J., Catholics, marriage and Holy Communion, The State JournalRegister, 15-VII-2016 [goo.gl/0VULOz].

PÉREZ Soba, J., Interpretar a partir del corazón del Evangelio, InfoCatólica, 23II-2016 [goo.gl/yY2jWf].

—, «Amoris letitia» no es un cambio de doctrina, sino una invitación para un camino nuevo, InfoCatólica, 10-IV-2016 [goo.gl/f71LsQ].

—, Entrevista de Sergio Mora, Zenit, 11-IV-2016 [goo.gl/APX0bD].

Petrà, B., «Amoris Laetitia». Un passo avanti nella Tradizione, Il Regno-attualità 8 (2016) 243-251, 15-IV-2016 [goo.gl/Gjm79w].

Pierantoni, C., La crisi ariana e la controversia attuale su «Amoris laetitia»: un parallelo, http://www.chiesa.espressonline.it, 28-XI-2016 [goo.gl/f5gLDQ]. 
Rasmussen, E., Francisco, de disimulado a condenado, Religión Digital, 28-IV2016 [goo.gl/BCfMck].

Riccobaldi, G., Lettera, Settimo Cielo di Sandro Magister, 27-IX-2016 [goo.gl/Ffu93L].

Rodríguez LuÑo, A., La virtù dell'epicheia. Teoria, storia e applicazione (I). Dalla Grecia classica fino a F. Suárez, Acta Philosophica 6 (1997) 197-236.

—, La virtù dell'epicheia. Teoria, storia e applicazione (II). Dal cursus theologicus dei Salmanticenses fino ai nostri giorni, Acta Philosophica 7 (1998) 65-88.

—, «Amoris Laetitia»: Pautas doctrinales para un discernimiento pastoral, eticapolitica.net [goo.gl/FXWBQk].

Salvador y Conde, J., Epistolario de Santa Catalina de Siena. Espíritu y doctrina. II. Cartas 169 a 381, San Esteban, Salamanca 1982.

Sánchez Navarro, L., Sed misericordiosos. Misericordia y justicia, ¿incompatibles?, en N. Álvarez DE las Asturias (ed.), En la salud y en la enfermedad. Pastoral y derecho al servicio del matrimonio, Cristiandad, Madrid 2015, 17-42.

SAYÉs, J. A., La misericordia de Dios en la «Amoris laetitia», CatólicosOn-line. org [goo.gl/0rJjg0].

SCHNEIDER, A., Il paradosso delle interpretazioni contraddittorie di «Amoris laetitia», Veri Catholici, 24-IV-2016 [goo.gl/DUh4Zk].

SCHÖNBORN, Ch., Intervento nella conferenza stampa per la presentazione dell' Esortazione Apostolica post-sinodale del Santo Padre Francesco «Amoris Laetitia», sull'amore nella famiglia, 8-IV-2016 [goo.gl/kkt73n].

-, Matrimonio e conversione pastorale. Intervista di Antonio Spadaro al cardinale Cristoph Schönborn, La Civiltà Cattolica, n. 3966, 26-IX-2015 [goo.gl/ OxqnTq].

—, Excerpt from Conversation with Cardinal Schönborn about Amoris Laetitia (Intervista di A. Spadaro), La Civiltà Cattolica [goo.gl/fU2RX7].

SChooyans, M., Dalla casuistica alla misericordia. Verso una nuova arte di piacere?, La nuova Bussola Quotidiana, 12/19-VI-2016 [goo.gl/DuZUHJ].

Sebastián, F., ¿Amoris Laetitia ambigua?, Vida Nueva, n. 3002 (10/16-IX2016), 9-IX-2016 [goo.gl/1bE6X7].

SeIfert, J., Die Freude der Liebe: Freuden, Betrübnisse und Hoffnungen, Katholisches.info, 3-VIII-2016 [goo.gl/bg7vTP].

SILVAS, A. M., Some Concerns about «Amoris Laetitia» [goo.gl/Ity7jW].

SPADARO, A., Struttura e significato dell'Esortazione apostolica post-sinodale di papa Francesco, La Civiltà Cattolica, n. 3980, 23-IV-2016, 105-128. 
SpaDARO, A. - CAMELI, L. J., La sfida del discernimento in «Amoris Laetitia», La Civiltà Cattolica, n. 3985, 9-VII-2016, 3-16, citada por The gift and challenge of discernment in «The foy of Love», America. The National Catholic Review, 1/8-VIII-2016 [goo.gl/A5hz1R].

Spaemann, R., Entrevista de Anian Cristoph Wimmer, CNA/InfoCatólica, 29IV-2016 [goo.gl/VdQQna].

—, Nota, Die Tagespost/InfoCatólica, 17/20-VI-2016 [goo.gl/tEOwXv].

Touze, L., El reino de la misericordia en las enseñanzas de los papas Pablo VI, Juan Pablo II, Benedicto XVI y Francisco, Collationes, 3-VI-2016 [goo.gl/ZyHpxw].

VALLINI, A., «La letizia dell'amore»: il cammino delle famiglie a Roma, 19-IX2016 [goo.gl/9H2hf2].

Vesco, J.-P., Avec «Amoris laetitia», le pape François a fait œuvre de tradition, La Croix Urbi\&Orbi, 30-VI-2016 [goo.gl/fUognC].

VILlegas, S. B., «Amoris Laetitia». In the fubilee of Mercy, The Official Website of The Catholic Bishops' Conference of the Philippines, 9-IV-2016 [goo.gl/Q1gjJV].

VIngt-Trois, A., Pour un «art du discernement», fr.Zenit.org, 8-IV-2016 [goo.gl/N74ixj].

WoOdall, G., «Amoris laetitia», conciencia y discernimiento, CatolicosOn-line. org [goo.gl/tq 7wTr]. 
